\title{
Infections at the nexus of metabolic-associated fatty liver disease
}

\author{
Joost Boeckmans ${ }^{1,2}\left(\right.$ D $\cdot$ Matthias Rombaut ${ }^{1} \cdot$ Thomas Demuyser $^{3,4} \cdot$ Baptist Declerck $^{3} \cdot$ Denis Piérard $^{3}$. \\ Vera Rogiers ${ }^{1}$. Joery De Kock ${ }^{1} \cdot$ Luc Waumans $^{2} \cdot$ Koen Magerman $^{2,5} \cdot$ Reinoud Cartuyvels $^{2} \cdot$ Jean-Luc Rummens $^{2}$. \\ Robim M. Rodrigues ${ }^{1} \cdot$ Tamara Vanhaecke $^{1}$
}

Received: 1 December 2020 / Accepted: 29 April 2021 / Published online: 24 May 2021

(c) The Author(s), under exclusive licence to Springer-Verlag GmbH Germany, part of Springer Nature 2021

\begin{abstract}
Metabolic-associated fatty liver disease (MAFLD) is a chronic liver disease that affects about a quarter of the world population. MAFLD encompasses different disease stadia ranging from isolated liver steatosis to non-alcoholic steatohepatitis (NASH), fibrosis, cirrhosis and hepatocellular carcinoma. Although MAFLD is considered as the hepatic manifestation of the metabolic syndrome, multiple concomitant disease-potentiating factors can accelerate disease progression. Among these risk factors are diet, lifestyle, genetic traits, intake of steatogenic drugs, male gender and particular infections. Although infections often outweigh the development of fatty liver disease, pre-existing MAFLD could be triggered to progress towards more severe disease stadia. These combined disease cases might be underreported because of the high prevalence of both MAFLD and infectious diseases that can promote or exacerbate fatty liver disease development. In this review, we portray the molecular and cellular mechanisms by which the most relevant viral, bacterial and parasitic infections influence the progression of fatty liver disease and steatohepatitis. We focus in particular on how infectious diseases, including coronavirus disease-19, hepatitis $\mathrm{C}$, acquired immunodeficiency syndrome, peptic ulcer and periodontitis, exacerbate MAFLD. We specifically underscore the synergistic effects of these infections with other MAFLD-promoting factors.
\end{abstract}

Keywords Metabolic-associated fatty liver disease (MAFLD) $\cdot$ Non-alcoholic steatohepatitis (NASH) $\cdot$ Infectious diseases · Lipid metabolism · Liver · SARS-CoV-2 - Human immunodeficiency virus · Hepatitis C $\cdot$ Helicobacter pylori . Klebsiella pneumoniae

Robim M. Rodrigues and Tamara Vanhaecke contributed equally to this work.

Joost Boeckmans

Joost.Boeckmans@vub.be

$\triangle$ Robim M. Rodrigues

Robim.Marcelino.Rodrigues@ vub.be

1 Department of In Vitro Toxicology

and Dermato-Cosmetology, Faculty of Medicine

and Pharmacy, Vrije Universiteit Brussel, Laarbeeklaan 103, 1090 Brussels, Belgium

2 Clinical Laboratory, Jessa Hospital, Stadsomvaart 11, 3500 Hasselt, Belgium

3 Department of Microbiology, Universitair Ziekenhuis Brussel, Laarbeeklaan 101, 1090 Brussels, Belgium

4 Center for Neurosciences, Faculty of Medicine and Pharmacy, Vrije Universiteit Brussel, Laarbeeklaan 103, 1090 Brussels, Belgium

5 Department of Immunology and Infection, Hasselt University, Martelarenlaan 42, 3500 Hasselt, Belgium

\section{Introduction}

Metabolic-associated fatty liver disease (MAFLD) is a chronic liver disease that affects about $25 \%$ of the global population (Younossi et al. 2019; Ryaboshapkina and Hammar 2017). MAFLD comprises an umbrella of disease stadia ranging from liver steatosis to more severe nonalcoholic steatohepatitis (NASH), fibrosis, cirrhosis and hepatocellular carcinoma. Most MAFLD patients suffer from the metabolic syndrome in which obesity is one of the most important risk factors along with insulin resistance and type 2 diabetes. The development of steatosis and progression to more severe disease stadia are, however, multifactorial. A considerable number of patients is lean and certain genetic polymorphisms have been associated with a higher risk for MAFLD development and progression in the past decade (Younossi et al. 2018; Boeckmans et al. 2020a). In recent years, much attention has been paid to the involvement of the gut-liver axis in the NASH 
pathogenesis. NASH patients often exhibit dysbiosis and increased intestinal barrier permeability (Marra and Svegliati-baroni 2017). This can lead to translocation to the liver of pathogen-associated molecular patterns (PAMPs), of which lipopolysaccharide (LPS) is the best documented one, and contribute to NASH development and progression (Ganz and Szabo 2013). In addition, higher rates of ethanol-producing bacteria have been observed in the gut microbiome of NASH patients, suggesting that ethanol possibly also fulfills a role in the pathogenesis of NASH (Abu-Shanab and Quigley 2010). Apart from bacterial alterations in gut microbiota of MAFLD patients, also changes in fecal viromes have been recently found to relate with MAFLD severity (Lang et al. 2020). Notably, several infectious diseases can also lead directly or indirectly to lipid accumulation and inflammation in the liver. Therefore, we hypothesize that these pathological conditions aggravate MAFLD and hence synergistically worsen liver disease.

The infectious agents, for which an association with hepatic steatosis is best known, are Helicobacter pylori $(H$. pylori) (Tang and Kumar 2017), hepatitis C virus (HCV) and human immunodeficiency virus (HIV) (Cheung and Sanyal 2008; van Welzen et al. 2019). Yet, also other often less suspected infections may contribute to the progression or exacerbation of MAFLD. For example, the recent outbreak of the severe acute respiratory syndrome coronavirus 2 (SARS-CoV-2) that leads to coronavirus disease-19 (COVID-19), attracted much attention. Similar to the earlier reported SARS-CoV infections, admitted COVID19 patients showed disturbed liver laboratory parameters (Zhang et al. 2020; Cui et al. 2004). Moreover, it has been observed that MAFLD patients are more prone to develop severe COVID-19 and have a longer viral shedding time (Ji et al. 2020).

A direct link between a pathogen and MAFLD is seldomly evident, which highlights the need for increased awareness for these patients. A fatty liver is associated with recurrent bacterial infections independent of metabolic syndrome (Nseir et al. 2011), which makes this patient group especially at risk for shared and superimposed pathogenic mechanisms that can lead to fatty liver disease progression. This also applies to patients suffering from diabetes, in particular to those having type 1 diabetes (Carey et al. 2018). Nonetheless, pathogen-induced fatty liver can in certain cases be considered as a distinct entity, which is substantiated by the fact that hepatitis $\mathrm{C}$-induced steatosis disappears after successful antiviral treatment, while the 'metabolic fat' remains present (Asselah et al. 2006).

Here, we review the most relevant viral, bacterial and parasitic infectious diseases that are known to intertwine in the MAFLD pathogenesis or are suspected to do so. We specifically allude to alternative molecular mechanisms related to infectious agents that might play a role in MAFLD development and progression.

\section{Viruses}

Since decades, several viral infectious diseases are known to induce fatty liver disease-related features, including hepatitis $\mathrm{C}$ and acquired immunodeficiency syndrome (AIDS) (Sheikh et al. 2008; van Welzen et al. 2019). Notably, links between infectious agents and MAFLD have been also reported regarding infections caused by coronaviruses, yellow fever virus, dengue virus and the hepatitis E virus (Boeckmans et al. 2020b; Simões Quaresma et al. 2005; Kularatne et al. 2014; Lenggenhager et al. 2020). Although much less evidence is present for the latter to effectively promote or exacerbate MAFLD, specific connections between both pathologies can be made.

\section{Coronaviruses}

Coronaviruses have caused several epidemics in the past 20 years. SARS-CoV and SARS-CoV-2 infect humans using angiotensin converting enzyme 2 (ACE2) for cellular entry while the Middle East respiratory syndrome coronavirus (MERS-CoV) uses dipeptidyl peptidase 4 (DPP4) as a receptor for cellular entry (Kuba et al. 2005; Hoffmann et al. 2020). There is no conclusive evidence that ACE2 is expressed in hepatocytes which potentially could be at the basis of viral replication of SARS-CoV and SARS-CoV-2 (Hamming et al. 2004; De Smet et al. 2020). Nonetheless, based on single-cell RNA sequencing, it was found that ACE2 is expressed in cholangiocytes (Pawlotsky 2020). DPP4, on the other hand, is expressed by hepatocytes (Baumeier et al. 2017) and patients infected with MERS-CoV exhibit moderate liver steatosis, scattered calcifications and mild portal tract and lobular lymphocytic inflammation ( $\mathrm{Ng}$ et al. 2020). MERS-CoV can induce interleukin 1 receptor associated kinase 3 (IRAK-M), peroxisome proliferator-activated receptor (PPAR) $-\gamma$ and interleukin (IL)-10 in macrophages, and therefore, lead to undesired immunosuppression. DPP4 inhibitors such as sitagliptin are indicated for the treatment of insulin resistance and type 2 diabetes. Although clinical evidence is lacking, diabetes patients that take DPP4 inhibitors could be relatively protected against MERS-CoV infection (Al-Qahtani et al. 2017). On the other hand, intake of blood pressure-reducing ACE inhibitors and angiotensin II type-I receptor blockers can increase the expression of ACE2 which might lead to a 
higher susceptibility for developing COVID-19 (Boeckmans et al. 2020b; Fang et al. 2020).

\section{MAFLD and COVID-19 are interrelated}

Considering that MAFLD patients often suffer from hypertension, insulin resistance and type 2 diabetes, their specific position during the SARS epidemics was and is largely unknown. Furthermore, COVID-19 patients show a higher occurrence of hepatic steatosis measured by thorax CT (Kreling et al. 2020) and SARS-CoV and SARS-CoV-2 infections are often accompanied by abnormal levels of aspartate aminotransferase (AST) and alanine aminotransferase (ALT) serum levels which suggest liver damage (Zhang et al. 2020; Cui et al. 2004). In addition, suffering from MAFLD increases the risk for developing severe COVID-19 in both diabetic and non-diabetic patients (Gao et al. 2020; Dongiovanni et al. 2020; Pan et al. 2020).

\section{Possible explanations for MAFLD progression during COVID-19}

One possible explanation for MAFLD progression in COVID-19 patients is that ACE2 is highly expressed on enterocytes in the small intestine (Fig. 1). This might lead to increased gut permeability and translocation of PAMPs to the liver (Assante et al. 2020). Hereby, the liver could get primed for the cytokine storm, which is a systemic hyperinflammatory reaction in response to SARS-CoV and MERS-CoV infections, including the release of tumor necrosis factor (TNF)- $\alpha$, IL-1 $\beta$, IL-2, IL-6, interferon (IFN)- $\alpha$, IFN- $\beta$, IFN- $\gamma$, and $\mathrm{C}-\mathrm{C}$ chemokine ligand (CCL) 2 (Yi et al. 2020), that could consequently exacerbate liver inflammation and promote MAFLD progression (Assante et al. 2020). In addition, COVID-19 patients needing intensive care exhibited higher plasma levels of IL-2, IL-7, IL-10, colony-stimulating factor 2 (CSF2), CXCL10, CCL2, CCL3, and TNF- $\alpha$ compared to patients that were not admitted to the intensive care unit (Huang et al. 2020). CCL2 is an

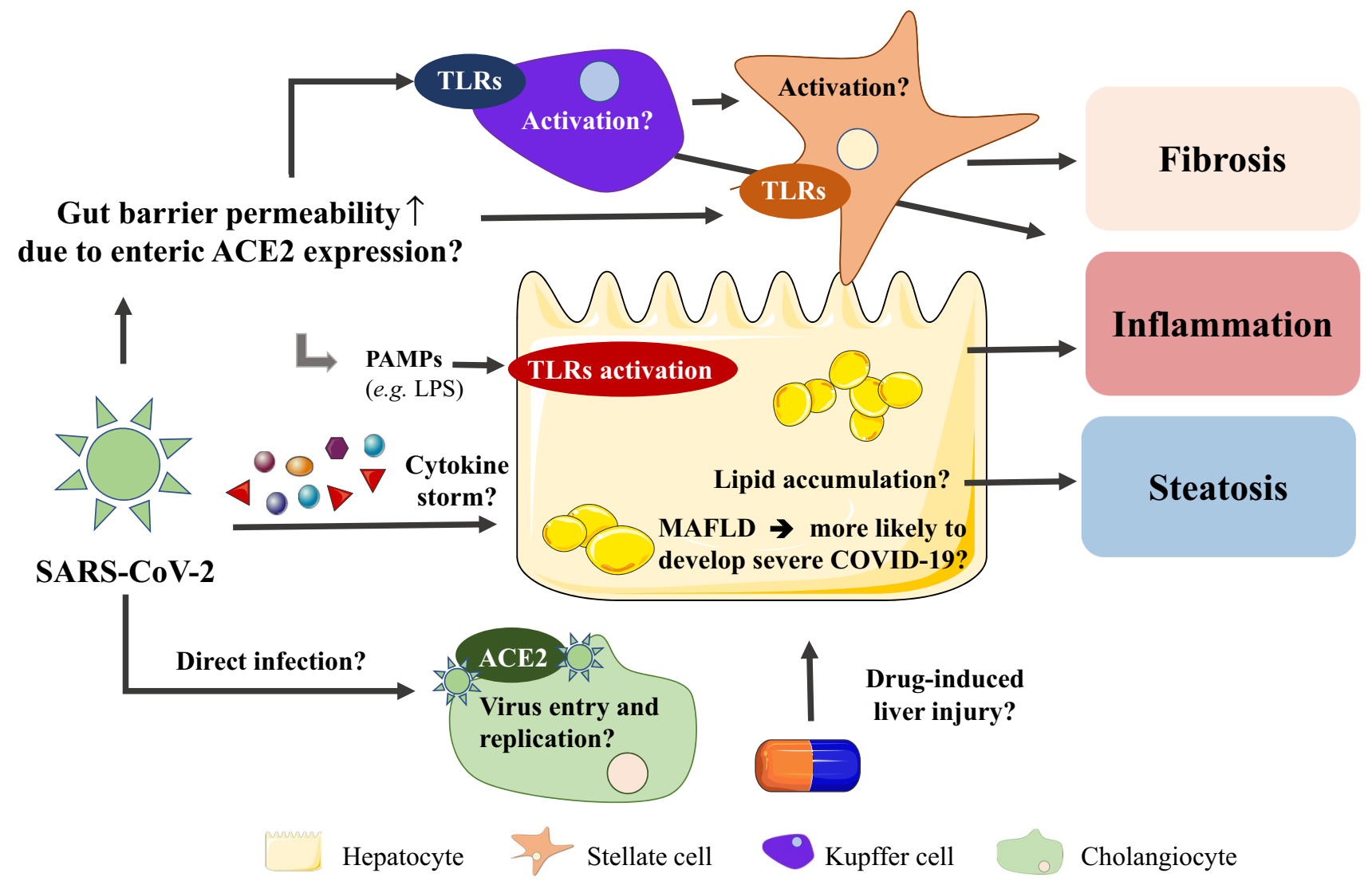

Fig. 1 Possible interconnections between COVID-19 and MAFLD. Disturbed liver laboratory parameters are frequently observed in severe COVID-19 cases. Patients infected by SARS-CoV-2 often exhibit also liver steatosis, while MAFLD seems to aggravate COVID-19. SARS-CoV-2 could induce PAMP translocation from the gut to the liver to initiate Kupffer cell and stellate cell activation and hence promote an acute inflammatory response. Further, the liver could get damaged or primed for secondary hits by cytokines during cytokine storms. Until today, cholangiocytes are the only liver cells known to express the virus entry receptor ACE2, although specific consequences remain to be investigated 
important inflammatory mediator and potent chemoattractant for monocytes and it fulfills a key role in the pathogenesis of NASH (Gao and Tsukamoto 2016). Moreover, earlier research pointed out that CXCL10 and TNF- $\alpha$ serum levels are increased in NASH patients (Zhang et al. 2014; Haas et al. 2019; Manco et al. 2007). Hence, patients suffering from pre-existing hepatic steatosis could possibly progress to more advanced liver disease because of certain cytokines that are involved in the pathogeneses of both the viral infection and NASH itself. These overlapping disease characteristics might be present due to the fact that the liver holds a large pool of tissue macrophages (i.e., Kupffer cells) that could compromise liver function. The alterations in gut permeability and bacterial translocation might not only explain the relation between COVID-19 and MAFLD, but also with inflammatory bowel disease, type 2 diabetes and obesity (Assante et al. 2020).

\section{Hepatitis C}

$\mathrm{HCV}$ is an enveloped positive-sense single-stranded RNA virus that belongs to the Flaviviridae family and causes chronic hepatitis $\mathrm{C}(\mathrm{CHC})$. The HCV virion contains a nucleocapsid with a host-derived membrane comprising E1 and E2 viral glycoproteins (Gastaminza et al. 2010; Zhu et al. 2014). HCV particles bind onto low-density lipoproteins (LDL) and very-low-density lipoproteins (VLDL) to form 'lipo-viro-particles (LVP)'. Viral entry is mediated by scavenger receptor class B type I (SR-BI), cluster of differentiation (CD) 81 and claudin 1 (CLDN1) (Miao et al. 2017; Bugianesi et al. 2006). HCV has been also shown to bind on diacylglycerol acyltransferase-1 (DGAT1) with its nucleocapsid core, further accentuating the close tie between HCV infection and the lipid metabolism of liver cells (Herker et al. 2010).

About $2.5 \%$ of the world population is infected by HCV. Seventy percent of these cases is accompanied by liver steatosis and about 20\% suffers from liver cirrhosis (Petruzziello et al. 2016). Concomitant presence of CHC and MAFLD has been shown to cause disease progression or prevent effective curative therapy (Brown 2008; Patel and Harrison 2012). Patients suffering from $\mathrm{CHC}$ have an 11-times higher risk for developing type 2 diabetes in comparison to high-risk patients without CHC. Furthermore, suffering from CHC also seems to increase the risk for developing type 2 diabetes in patients without predisposing factors (Mehta et al. 2003). Hepatic steatosis during chronic HCV infection stimulates necroinflammation and fibrosis (Adinolfi et al. 2001). In addition, the existence of a ' $\mathrm{HCV}$-associated dysmetabolic syndrome' has been postulated as a possible molecular basis for the presence of metabolic syndrome features in patients suffering from hepatitis C (Sheikh et al. 2008; Fletcher et al. 2008).
$\mathrm{HCV}$ is characterized by different genotypes (Zein 2000) that intertwine with MAFLD via distinctive molecular mechanisms (Adinolfi et al. 2016) (Fig. 2).

$\mathrm{HCV}$ has been shown to down-regulate PPAR- $\alpha$ (Dharancy et al. 2005), which diminishes fatty acid $\beta$-oxidation as it targets carnitine palmitoyl acyl-CoA transferase 1A (CPT1A), a key enzyme for mitochondrial fatty acid import (Boeckmans et al. 2020a; Cheng et al. 2005). PPARA expression is also decreased in NASH (Francque et al. 2015), which substantiates the similarities between both pathologies. The fact that PPAR- $\alpha$ activation reduces nuclear factor kappa $\mathrm{B}(\mathrm{NF}-\kappa \mathrm{B})$ and activator protein (AP)-1-mediated inflammation suggests that PPAR- $\alpha$ downregulation by $\mathrm{HCV}$ could be a mechanism of $\mathrm{HCV}$ to escape protective host response (Dharancy et al. 2005).

HCV genotypes 1 and 4 have been mainly associated with insulin resistance (Moucari et al. 2008). Of note, liver samples of patients suffering from hepatitis $\mathrm{C}$ exhibit a lower expression of insulin receptor substrate (IRS) 1 and IRS2, inducing IR. This is, however, restored after clearance of the virus. HCV causes proteasomal degradation of IRS1 and IRS2 that are essential for further insulin signaling through phosphoinositide 3-kinase (PI3K) and Akt (Alsatie et al. 2008; Kawaguchi et al. 2004, 2007). Furthermore, diabetic hepatitis $\mathrm{C}$ patients exhibit increased levels of soluble TNF- $\alpha$ receptors. TNF- $\alpha$ can cause detrimental effects on insulin signaling through inhibition of tyrosine kinase activity of the insulin receptor for the phosphorylation and activation of IRS1 (Knobler et al. 2003; Knobler and Schattner 2005). In addition, the levels of soluble TNF- $\alpha$ receptors (in particular sTNF-R75) correlate with histological hepatitis $C$ severity, but not with genotype or quantitative viremia (Zylberberg et al. 1999). Besides worsening insulin resistance and inflammation, patients suffering from $\mathrm{HCV}$ genotype 1 infection and liver steatosis also exhibit higher hepatic expression of fatty acid translocase (FAT) (syn. CD36). CD36 is a fatty acid transporter whose expression is also elevated in NASH livers and relates to insulin resistance, hyperinsulinemia and MAFLD (Miquilena-Colina et al. 2011). Apart from the involvement of CD36 in lipid metabolism, it has also been shown that CD36 interacts with HCV glycoprotein E1 that could be a co-receptor for HCV entry (Cheng et al. 2016).

Hepatic steatosis has been reported to accelerate the progression of liver damage, by means of necroinflammatory activity and fibrosis progression in patients suffering from HCV genotype 3 infection (Adinolfi et al. 2001). However, in these patients, but not in individuals infected by the HCV genotype 1 or 4 , steatosis evades upon effective treatment which points to a direct role of the virus in lipid metabolism irrespective of secondary risk factors for MAFLD (Kumar et al. 2002). Yet, this also substantiates 


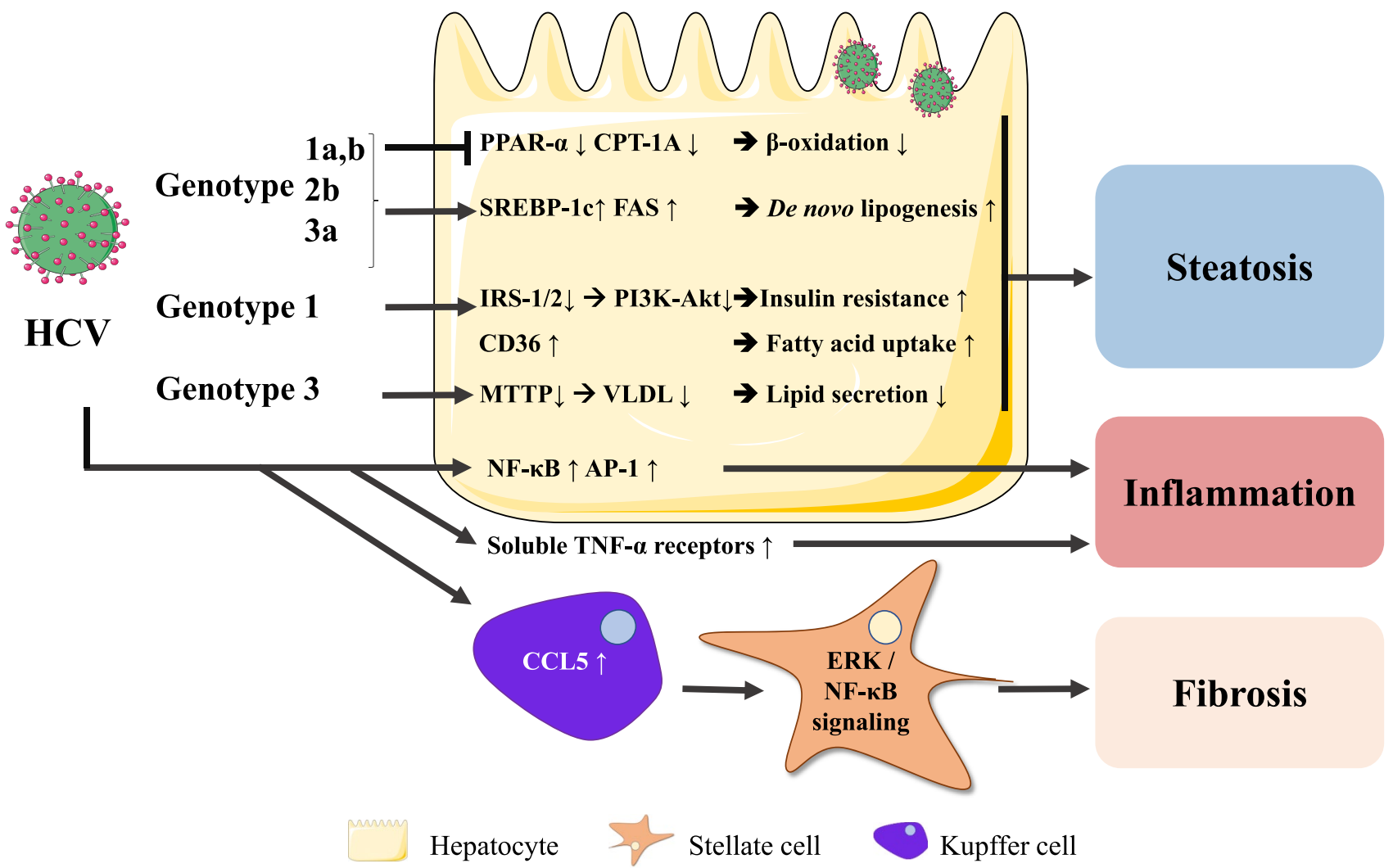

Fig. $2 \mathrm{HCV}$-mediated mechanisms leading to hepatic steatosis and inflammation. HCV infection leads to SREBP-1c-mediated lipid accumulation and PPAR- $\alpha / P P A R A$ and CPTA downregulation, suggesting impaired fatty acid $\beta$-oxidation and reduced repression of

the presence of different pathogenic mechanisms that both require specific treatment strategies.

$\mathrm{HCV}$ genotypes $1 \mathrm{a}, 1 \mathrm{~b}, 2 \mathrm{~b}$ and $3 \mathrm{a}$ have been found to induce fatty acid synthase (FAS) expression through sterol regulatory element-binding protein (SREBP)-1c. HCV genotype 3a causes a stronger SREBP-1c-mediated induction of FAS than the 1 b genotype, which points to a genotype-specific effect that also correlates with the clinical observations (Waris et al. 2007; Jackel-Cram et al. 2007). Hypobetalipoproteinemia has also been linked to HCV genotype $3 \mathrm{a}$ infection. This virus is thought to inhibit the microsomal triglyceride transfer protein (MTTP) that mediates VLDL assembly from ApoB and lipids, resulting in impaired VLDL secretion and thus intracellular lipid accumulation in hepatocytes (Serfaty et al. 2001; Gordon and Jamil 2000; Chan et al. 2017).

Although HCV is not known to directly infect hepatic stellate cells (Florimond et al. 2015), it has been shown that HCV-exposed Kupffer cells secrete CCL5 that triggers NF- $\kappa \mathrm{B}$ and ERK signaling in stellate cells, resulting in the expression of genes encoding pro-inflammatory (NLR Family Pyrin Domain Containing 3 (NLRP3), IL1B, IL-6 and CCL5) and pro-fibrotic (transforming growth factor inflammation. HCV genotypes 1 and 4 infections are associated with insulin resistance, while HCV genotype 3 infection impairs VLDLmediated triglyceride secretion. HCV-exposed Kupffer cells secrete CCL5 resulting in hepatic stellate cell activation

(TGF- $\beta 1$ ), collagen 4A1 (COL4A1), matrix metallopeptidase 2 (MMP2) and $\alpha$-smooth muscle actin ( $\alpha$-SMA)) markers (Sasaki et al. 2017). The pro-inflammatory and -fibrotic interplay between non-parenchymal liver cells in hepatitis $\mathrm{C}$ shares important mechanisms with triggers that promote fatty liver disease progression, including Kupffer cell CCL5 secretion (Boeckmans et al. 2018), accentuating the relationship between both pathogeneses.

\section{Hepatitis A, B, D and E}

In comparison to hepatitis $\mathrm{C}$, less evidence is available for the involvement of hepatitis $\mathrm{A}, \mathrm{B}, \mathrm{D}$ and $\mathrm{E}$ in fatty liver disease development and progression.

The hepatitis A virus (HAV) is a positive-sense singlestranded RNA virus that belongs to the Picornaviridae family. HAV is mainly transmitted through the oral-fecal route by for example contaminated food (Lin et al. 2017). It has been suggested that past exposure to HAV protects against advanced fibrosis in MAFLD. Reasons behind this protective effect could be a reversal of the imbalance between pro- and anti-inflammatory cytokines and early-age gut colonization 
with orofecal microbes that could exert a hepatoprotective effect (de Silva et al. 2008).

The hepatitis B virus (HBV) is a DNA virus that belongs to the family of Hepadnaviridae (Liang 2009). About 300 million people are chronically infected with HBV (MacLachlan and Cowie 2015) and evidence has been provided that HBV infection can result in cirrhosis and hepatocellular carcinoma (Giovanna et al. 2008). HBV does not require a cell type-specific target for cellular attachment (Urban et al. 2010). It binds the heparan sulfate proteoglycans at the cell surface, which is then followed by a hepatocytespecific interaction of the HBV surface L-protein with $\mathrm{Na}^{+}$-taurocholate co-transporting polypeptide (NTCP) (Yan et al. 2012; Ni et al. 2014). HBV infection has been shown to inversely correlate with the risk for MAFLD (Xiong et al. 2017), probably because HBV infection inversely associates with the metabolic syndrome (Jan et al. 2006). HBV infection negatively relates to hypoalphalipoproteinemia (Zhao et al. 2018) and seems to lower the risk for developing dyslipidemia (Joo et al. 2019). Based on these studies, HBV and MAFLD comorbidity appears to decrease the progression or severity of these diseases. In contrast, it was recently reported that patients suffering from NASH and chronic hepatitis B have more advanced liver fibrosis and die earlier or develop in a shorter time liver-related outcomes than patients without NASH (Choi et al. 2020), suggesting a synergistic effect in the more advanced disease states.

The hepatitis D virus (HDV) holds a circular singlestranded RNA genome and is not classified in a family. HDV infection occurs through parenteral transmission and requires HBV co-infection to be infectious (Taylor 2018). Seen the increasing control of hepatitis B through vaccination, hepatitis $\mathrm{D}$ is considered a disappearing disease (Khuroo and Sofi 2020).

The hepatitis E virus (HEV) is a positive-sense singlestranded RNA virus that belongs to the Hepeviridae family. The HEV is enterically transmitted and is a leading cause of acute viral hepatitis (Lhomme et al. 2020). Hepatitis E is considered as a factor that can cause 'acute on chronic hepatitis' (Frias et al. 2018) and MAFLD/NASH cases have been reported as well (Davern et al. 2011; Lenggenhager et al. 2020). Yet, the mechanisms by which HEV may contribute to the development of MAFLD have not been documented.

\section{Human immunodeficiency viruses}

HIV is a single-stranded RNA virus that belongs to the family of Retroviridae and is subdivided in HIV-1 and HIV-2 (Seitz 2016). About 14,000 people are infected every day by HIV (Eilami et al. 2019). Fatty liver occurs in up to $48 \%$ of HIV-infected patients (van Welzen et al. 2019) and is accompanied by inflammation and fibrosis when compared to uninfected patients (Papagianni and Tziomalos 2018; Vodkin et al. 2015). Nonetheless, the occurrence of steatosis-promoting factors is similar between HIV-infected patients and the general population (Macías et al. 2017). Besides metabolic inducers, multiple HIV-specific factors are thought to contribute to MAFLD in HIV-infected patients, including the virus itself, gut-liver axis and highly active antiretroviral therapy (HAART) (Vallet-Pichard et al. 2012). Since cardiovascular complications are common in HIV-infected patients (Low et al. 2019; So-Armah and Freiberg 2018), and cardiovascular disease is a top-leading death cause in MAFLD patients (Paik et al. 2019), synergistic effects seem possible.

\section{Effects of HIV on distinct liver cell populations}

HIV uses the CD4 receptor on T-helper cells (Seitz 2016) for cellular attachment. Further entry is mediated by, among others, the $\mathrm{C}-\mathrm{C}$ chemokine receptor 5 (CCR5) and $\mathrm{C}-\mathrm{X}-\mathrm{C}$ chemokine receptor 4 (CXCR4) (Dean et al. 1996; Feng et al. 1996). CD4 is not expressed in hepatocytes, although its co-factor for cellular entry, CXCR4, is present (Vlahakis et al. 2003). Apoptosis induced by HIV interaction (via gp120) with CXCR4 expressed by hepatocytes has been reported (Vlahakis et al. 2003), which is a distinctive feature of NASH compared to benign liver steatosis (Boeckmans et al. 2018). On the other hand, HIV is able to infect Kupffer cells, the liver resident macrophages (Ganesan et al. 2018). $\mathrm{CD} 4+\mathrm{T}$ cell depletion leads to increased gut barrier permeability resulting in translocation of PAMPs to the liver (Somsouk et al. 2015; Rocafort et al. 2019). HIV-infected Kupffer cells exhibit increased expression of Toll-like receptor 4 (TLR4) and CD14 along with an increased release of TNF- $\alpha$, IL- 6 and IL-1 $\beta$ in response to LPS (Mosoian et al. 2017; Zhang et al. 2019) (Fig. 3). This sequence of events is substantiated by the fact that liver tissue obtained from HIV-positive patients exhibits in situ IL- $1 \beta$ expression in CD68+ cells (Zhang et al. 2019).

HIV infection of stellate cells results in increased collagen type 1 expression and CCL2 release that play prominent roles in the pathogenesis of NASH (Tuyama et al. 2010; Chamroonkul and Bansal 2019). Specific interaction of gp120 with stellate cells induces CCL2 secretion as well as expression of $I L-6$ and tissue inhibitor of metalloprotease- $I$ (TIMP1) (Bruno et al. 2010), which are known mediators of hepatic inflammation and fibrosis.

The interaction of HIV with TLR4 on both stellate cells and liver macrophages highlights the importance of TLR signaling in the inflammatory response of the liver triggered by HIV (Del Cornò et al. 2016).

\section{Anti-HIV treatment promotes MAFLD development}

HAART (Seth 2019), i.e., intake of nucleoside reverse transcriptase inhibitors (NRTIs), non-nucleoside reverse 


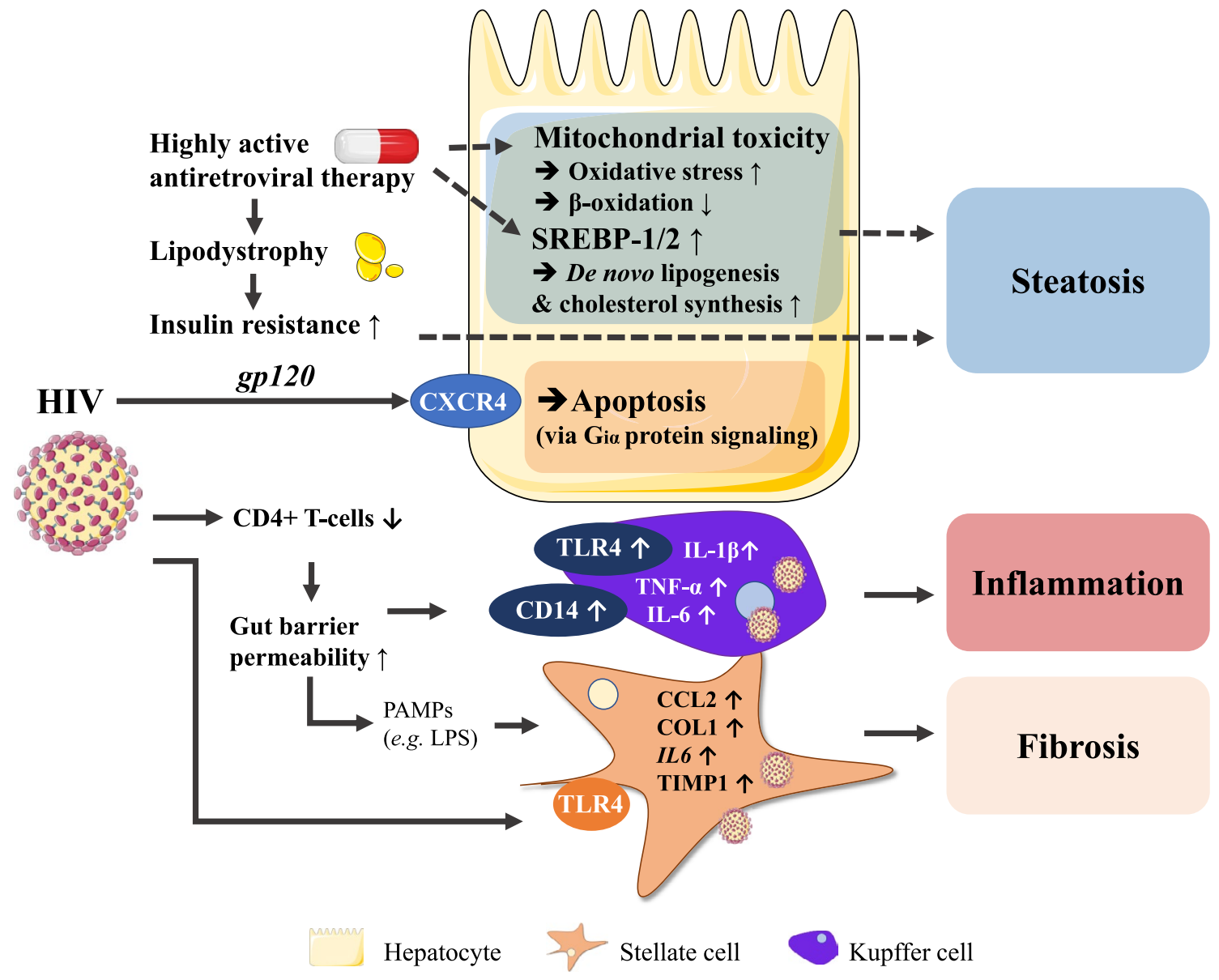

Fig. 3 HIV- and HAART-mediated mechanisms leading to hepatic steatosis, inflammation and fibrosis. HIV itself can induce liver inflammation via TLRs, hepatocyte apoptosis through CXCR4 and fibrosis by directly (via envelope glycoprotein gp120) and indirectly (via LPS) activating stellate cells. HAART-associated lipodystrophy induces insulin resistance and hepatic steatosis while also evoking mitochondrial toxicity transcriptase inhibitors and protease inhibitors (PIs) (Shafer and Vuitton 1999), is often accompanied by lipodystrophy, a process culminating in the lack of adipocytes to store (excess) fatty acids and triglycerides (Polyzos et al. 2009, 2019).

NRTIs, especially thymidine analogues, evoke hypoadiponectinemia, hypertriglyceridemia and lipodystrophy. Among the NRTIs, stavudine and didanosine are also known to exert mitochondrial toxicity that could lead to the generation of reactive oxygen species and impair fatty acid $\beta$-oxidation (White 2001; Feeney and Mallon 2010). These patients exhibit microvesicular hepatic steatosis, which correlates with more advanced MAFLD histology (Tandra et al. 2011). Intake of PIs, on the other hand, can result in insulin resistance through inhibition of GLUT4 (Yan and Hruz 2005). Ritonavir has been shown to induce SREBP-1 and SREBP-2 translocation to the nucleus in mice, transcription factors known to promote lipogenesis and cholesterol biosynthesis, which could lay at the origin of fatty liver development (Riddle et al. 2001). HAART can also alter growth hormone secretion that associates with lipodystrophy (Rochira and Guaraldi 2017). Insulin resistance, along with induced lipodystrophy, can lead to body fat redistribution and hepatic steatosis (ValletPichard et al. 2012). HIV-1 is known to suppress PPAR- $\gamma$ transcriptional activity and adipocyte differentiation (Shrivastav et al. 2008; Otake et al. 2004) and this mechanism can hence also contribute to the HAART-mediated lipodystrophy.

\section{HIV and anti-MAFLD treatment}

Patients suffering from HIV infection are often excluded from clinical trials because of possible drug-drug interactions. Yet, considering the burden of MAFLD among HIVinfected patients, it is of utmost importance to also evaluate 
novel therapies in these patients or to set up in vitro experiments with cells of human origin, infected or not. Moreover, cenicriviroc, a dual CCR2/CCR5 antagonist, is under development for both HIV infection and NASH treatment (Guaraldi et al. 2020) since the CCR2 and CCR5 receptors are common drug targets in both diseases.

\section{Human cytomegalovirus}

The human cytomegalovirus (CMV) is a DNA virus belonging to the Herpesviridae family. Over $40 \%$ of the world population is infected with CMV that persists latently throughout adulthood (Seitz 2010; Cannon et al. 2010). CMV can replicate in multiple cell types among which epithelial cells of gland and mucosal tissue, smooth muscle cells, fibroblasts, macrophages, dendritic cells, hepatocytes and vascular endothelial cells (Beltran and Cristea 2014).

\section{CMV-related MAFLD is dependent on gender and body mass index}

The correlation between CMV infection and metabolic risk factors for developing MAFLD appears to be gender- and body mass index (BMI)-specific. First, CMV infection seems to be associated with the metabolic syndrome only in females. Second, while normal weight CMV-immunoglobulin (Ig)G seropositive females exhibit a higher prevalence of dyslipidemia and metabolic syndrome, these effects are not shared with females suffering from extreme obesity that surprisingly showed to have higher HDL- and lower LDL cholesterol (Fleck-Derderian et al. 2017).

\section{CMV could promote MAFLD through de novo lipogenesis and oxidative stress}

In vitro analysis showed that CMV-infected human fibroblasts exhibit increased activity of ACC, which is the first rate-limiting enzyme in the de novo lipogenesis pathway and is regulated by SREBP-1c (Boeckmans et al. 2018). Mice expressing CMV-derived regulatory protein IE2 (UL122) showed increased gene- and protein expression of SREBP-1c, which was associated with hepatic steatosis (Zhang et al. 2018). Increased hepatic SREBP-1c levels indeed correlate with hepatic steatosis, although decreased levels relate to advanced NASH (Nagaya et al. 2010). This evokes the question whether CMV infection can effectively compromise liver functions. Fibroblasts infected with CMV exhibit stressed mitochondria that have an increased mass and membrane potential (Combs et al. 2019), which could lead to oxidative stress and hence MAFLD progression. Yet, it has been proposed that intracellular CMV could induce (compensatory) anti-oxidative effects to take more advantage from the host cell for replication. Indeed, CMV-infected human fibroblasts increase their production of enzymes that synthesize and utilize glutathione and activate specific NF-E2 related factor 2 (Nrf2) target genes that exert protective effects against oxidative stress (Tilton et al. 2011; Lee et al. 2013; Lee 2018). As such, although these results are of high experimental nature, MAFLD-inducing mechanisms might be abrogated due to virus-specific cellular alterations.

Future (human) studies should, however, take into account the specific roles of primary and reactivated infections (e.g., by measuring CMV DNA viral load) and explore whether CMV infection precedes the development of the metabolic syndrome or not (Fleck-Derderian et al. 2017).

\section{Dengue virus}

Dengue virus is a positive-sense single-stranded RNA virus that belongs to the family of the Flaviviridae and is transmitted by Aedes mosquitoes. About 50 million people get infected every year. Dengue disease can be asymptomatic but also manifest as the "dengue shock syndrome" leading to multiple organ failure with fatal outcome (Huy et al. 2013).

Tropism of the dengue virus is not well documented, but involves the immune system, liver, and endothelial blood vessel cells (Martina et al. 2009; Begum et al. 2019). Although the dengue shock syndrome resulting in multiple organ failure is the main cause of dengue virus-related death, deterioration of liver functions due to severe hemorrhagic liver necrosis with micro- and macrovesicular steatosis and periportal inflammatory infiltrate, has also been reported as a death cause (Kularatne et al. 2014).

Most information with regard to liver histology among dengue virus-infected patients is based on postmortem analyses. Liver tissue of children that died from dengue virus infection showed varying injury degree, including congestion of the liver sinusoids and hepatocyte cell death. Most reported cases exhibited liver steatosis accompanied by hepatocyte ballooning (Aye et al. 2014; Huerre et al. 2001), which is a hallmark of NASH (Kleiner et al. 2005). These effects have been confirmed in dengue-2 virusinfected BALB/c mice, that showed hepatocyte micro- and macro-steatosis, swelling and necrosis (Paes et al. 2009). Although these findings do not per se indicate a direct correlation between dengue virus infection and fatty liver disease/ steatohepatitis, dengue virus-infected patients with plasma leakage that suffer as well from MAFLD have more severe hemoconcentration, thrombocytopenia and prolonged hospital stay (Suwarto et al. 2018).

\section{Yellow fever virus}

The yellow fever virus (YFV) is a positive-sense singlestranded RNA virus that belongs to the Flaviviridae family. The YFV is also transmitted by Aedes mosquitoes and 
is endemic in Africa and South America, infecting about 200,000 persons every year. YFV infection is fatal in about $5 \%$ of the infected individuals (Waggoner et al. 2018). Infection can cause hepatocyte midzonal steatosis, apoptosis and lytic necrosis. The massive hepatocyte death during yellow fever is, however, mainly due to apoptosis (Simões Quaresma et al. 2005), which differentiates NASH from simple steatosis (Boeckmans et al. 2018). Analysis of liver biopsies from fatal yellow fever cases showed that the virusinduced hepatocyte apoptosis is likely mediated by TGF- $\beta$, TNF- $\alpha$ and natural killer cell activity (Quaresma et al. 2006). Although correlation studies are lacking, pre-existing NASH could potentially potentiate liver failure during yellow fever.

\section{Bacteria and parasites}

It has been well documented that bacterial infections that are not necessarily hepatotropic, can influence liver functionality and development of hepatic diseases (Minemura et al. 2014). Further, the dysfunction of the gut mucosal barrier (leaky gut) can lead to bacterial translocation from the gut to the liver via the gut-liver axis (Giannelli et al. 2014). Multiple bacteria, including H. pylori, K. pneumoniae, Chlamydia species and bacteria involved in periodontitis can specifically contribute to the progression of MAFLD (Upala et al. 2016; Yuan et al. 2019; Bolukbas et al. 2005; Marangoni et al. 2015; Alakhali et al. 2018).

Most research regarding parasitic infections and fatty liver disease concerns Plasmodium species. Although specific links exist between MAFLD and the parasitic infections discussed below, there is no general consensus for an important interrelationship. However, several lines of experimental evidence are present that infections caused by Plasmodium species, Schistosoma species, Toxoplasma gondii (T. gondii) and Trypanosoma cruzi (T. cruzi) are at the interface with MAFLD (Viriyavejakul et al. 2014; Chen et al. 2013; Huang et al. 2018; Lucchetti et al. 2019).

\section{Helicobacter pylori}

H. pylori is a commensal Gram-negative bacterium that mainly persists in the gastroduodenal mucosa where it can cause peptic ulcer (Brown 2000). About half of the world population is colonized with $H$. pylori which generally occurs before the age of 10 years (Cover and Blaser 2009). H. pylori infection seems to positively associate with the presence of the metabolic syndrome (Upala et al. 2016) and MAFLD (Liu et al. 2019; Wijarnpreecha et al. 2018; Mantovani et al. 2019).

\section{H. pylori-related MAFLD largely depends on fetuin $A$ and lipoproteins}

H. pylori-positive patients exhibited higher Homeostatic Model Assessment for Insulin Resistance (HOMA-IR) scores and fasting insulin serum levels compared to $H$. pylori-negative patients (Eshraghian et al. 2009). Moreover, H. pylori IgG seropositivity has been associated with hepatocyte ballooning (Sumida et al. 2015), which is characteristic of NASH (Zanto et al. 2010), suggesting a potential association between $H$. pylori infection and the progression of simple steatosis to NASH. A possible interaction mechanism between $H$. pylori infection and MAFLD involves fetuin A or alpha 2-HS glycoprotein (AHSG), which is a serum glycoprotein synthesized by hepatocytes that plays a role as a carrier of free fatty acids. Indeed, higher serum fetuin A levels in $H$. pylori-positive patients have been reported to correlate with impaired insulin sensitivity and glucose tolerance (Fig. 4) (Stefan and Häring 2013; Trepanowski et al. 2015). Increased fetuin A serum levels and hepatic gene expression have also been related to hepatic steatosis and NASH (von Loeffelholz et al. 2016; Kahraman et al. 2013). Furthermore, in vitro studies using rodent myoblasts indicated that fetuin A inhibits tyrosine kinase activity of the insulin receptor and blocks insulin-mediated glucose transporter type 4 (GLUT4) translocation and protein kinase $\mathrm{B}$ (Akt) activation, thereby promoting insulin resistance (Goustin et al. 2013). Fetuin A also acts as an endogenous adaptor protein for free fatty acid-mediated activation of TLR4 in mice. Activation of TLR4 typically results in an inflammatory response through activation of NF- $\kappa B$ and c-Jun N-terminal kinase (JNK) signaling pathways (Pal et al. 2012). This might reflect the presence of the wide panel of inflammatory mediators (c-reactive protein, TNF- $\alpha$, IL-6, IL-1 $\beta$ ) in patients suffering from $H$. pylori infection. These pleiotropic effects of fetuin A could, therefore, represent an alternative mechanism for steatohepatitis development during H. pylori infection. Besides increasing fetuin A levels, H. pylori infection could also contribute to gut barrier disruption leading to translocation of LPS and other PAMPs to the liver (Dash et al. 2019; Quesada-Vázquez et al. 2020) that are known activators of Kupffer cells and stellate cells to promote fibrosis (Boeckmans et al. 2018). In addition, $H$. pylori infection is associated with lower high-density lipoprotein (HDL) cholesterol serum values (Upala et al. 2016), known to promote dyslipidemia (Chatrath et al. 2012). $H$. pylori eradication increases HDL and decreases low-density lipoprotein (LDL) cholesterol (Niegawa et al. 2018), thereby restoring the cardioprotective activity of the HDL/ LDL ratio and decreasing the cardiovascular risk related to MAFLD (Sun et al. 2016). Furthermore, H. pylori eradication increases serum adiponectin levels (Ando et al. 2013), 


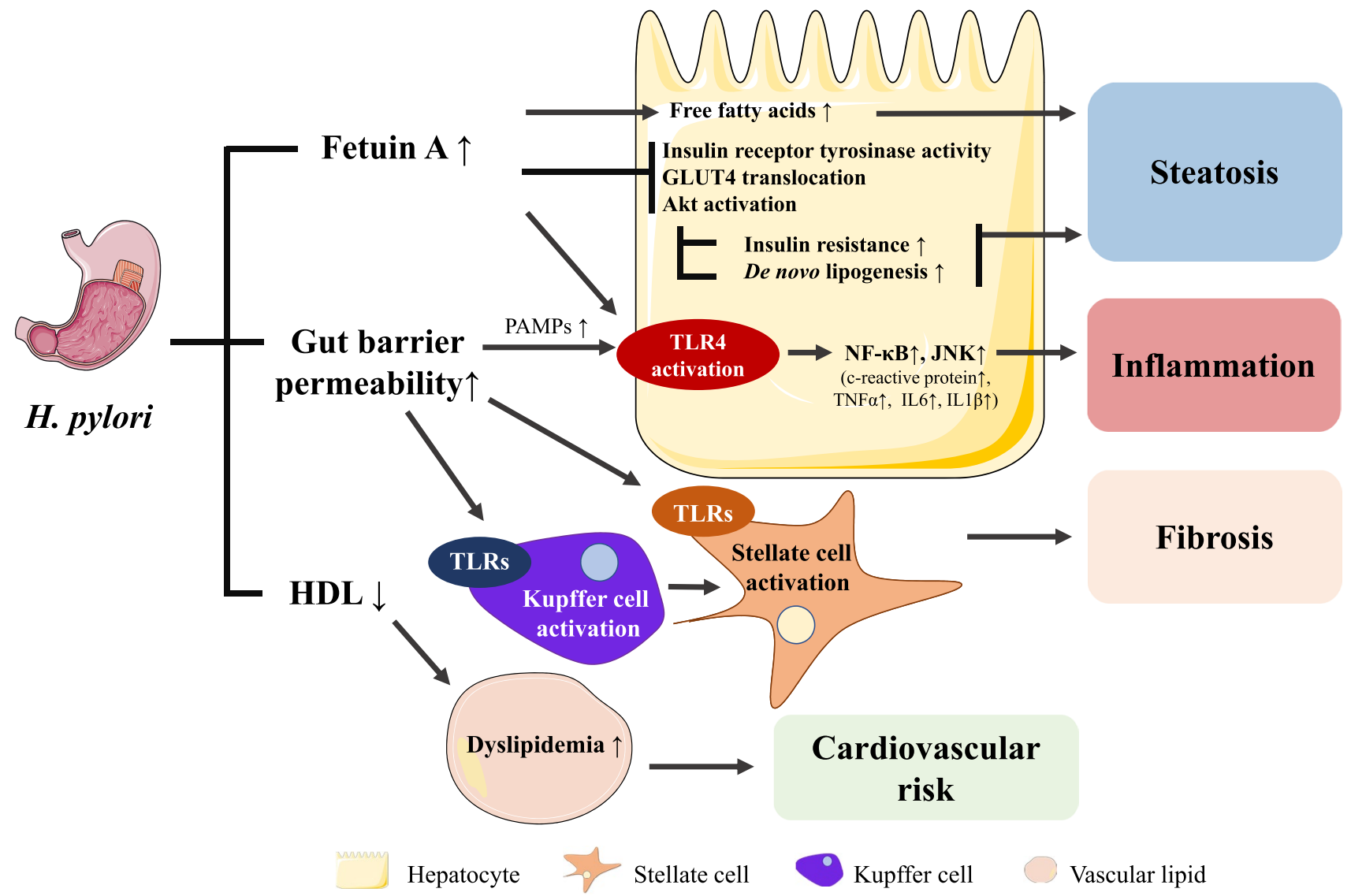

Fig. 4 H. Pylori-infection-mediated mechanisms leading to hepatic steatosis inflammation and fibrosis. H. Pylori infection relates to increased serum fetuin A levels. Fetuin A can impair insulin signaling by interrogating with, among others, insulin receptor tyrosine kinase

which could enhance insulin sensitivity and lead to wholebody metabolic improvements (Ando et al. 2013; Stern et al. 2016).

\section{Klebsiella pneumoniae}

Klebsiella pneumoniae (K. pneumoniae) is a commensal Gram-negative bacterium of the Enterobacterales order that can cause opportunist infections in the compromised (usually hospitalized) host (Paczosa 2016). It has been shown that alterations in gut microbiota may contribute to a series of diseases including type 2 diabetes, obesity and MAFLD (Abu-Shanab and Quigley 2010).

\section{Ethanol fulfills a role in the pathogenesis of MAFLD}

One particular aspect of alterations in gut microbiota in MAFLD is a shift towards ethanol-producing bacteria (Marra and Svegliati-baroni 2017), suggesting that ethanol also fulfills a role in the pathogenesis of MAFLD. In activity and promote inflammation through TLR4 activation. $H$. Pylori infection probably also relates to increased gut barrier permeability which can result in translocation of PAMPs to the liver through the gut-liver axis and initiate inflammation and fibrosis

that view, it has been observed that ethanol-producing $K$. pneumoniae are present in up to $60 \%$ of MAFLD patients. The causative role of $K$. pneumoniae was evidenced by oral gavage of clinical isolates in mice as well as fecal microbiota transplantation. When the ethanol-producing $K$. pneumoniae strain was selectively removed from the fecal transplant, the mice did not develop MAFLD (Yuan et al. 2019). The NASH-promoting effects induced by $K$. pneumoniae are at least in part due to mitochondrial dysfunction (Chen et al. 2020), leading to oxidative stress which is a hallmark of NASH (Buzzetti et al. 2016). Furthermore, liver-infiltrating T cells, neutrophils, macrophages, and B cells were more abundant in mice fed the ethanol-producing K. pneumoniae strain or ethanol (Yuan et al. 2019), indicating immune system activation. Hence, although clinical evidence is lacking, the presence of ethanol-producing $K$. pneumoniae in the gut can be considered as a risk factor for MAFLD. 


\section{Periodontitis}

Periodontitis is a chronic infectious disease in which an inflammatory response occurs due to the interplay between oral microorganisms and the host immune system (Pihlstrom et al. 2005).

\section{Suffering from periodontitis can increase the risk for MAFLD development.}

Although the number of prospective cohort studies is small, a systematic review concluded that periodontitis could enhance the risk for MAFLD development and progression (Alakhali et al. 2018). A periodontal probing pocket depth greater than $4 \mathrm{~mm}$ has been documented as a risk factor for MAFLD (Iwasaki et al. 2018) and the association between periodontitis and NASH is stronger when accompanied by significant liver fibrosis (Alazawi et al. 2017). Periodontitis has also been associated with poorly controlled type 2 diabetes (Salvi et al. 2008) as well as an increased prevalence and incidence of coronary heart disease (Bahekar et al. 2007). Considering that type 2 diabetes is a major risk factor for MAFLD (Finck 2018) and that cardiovascular disease is the leading death cause among MAFLD patients (Stefan et al. 2018), it is not surprising that periodontitis also occurs more frequently within this patient group.

\section{Multiple bacteria could be implicated in periodontitis-related MAFLD}

Multiple phyla have been related with periodontitis among which Bacteroidetes, Candidatus Saccharibacteria, Firmicutes, Proteobacteria, Spirochaetes, Synergistetes, Porphyromonas and Aggregatibacter (Pérez-Chaparro et al. 2014; Guentsch et al. 2009). Aggregatibacter actinomycetemcomitans (A. actinomycetemcomitans) is a Gram-negative perio-pathogenic bacterium that has been linked to localized aggressive periodontitis (Arora et al. 2015). It was found that higher occurrence of $A$. actinomycetemcomitans was associated with periodontitis in type 1 and type 2 diabetes patients (Castrillon et al. 2015) and that IgG seropositivity positively related with visceral fat, fasting plasma insulin levels, and HOMA-IR score. Using mice colonized with $A$. actinomycetemcomitans and fed a high-fat diet (HFD), it was demonstrated that additional administration of A. actinomycetemcomitans led to higher hepatic steatosis compared to mice that did not receive the microorganism. Furthermore, these mice also exhibited increased expression of genes related to glucagon and adipocytokine signaling and insulin resistance along with lower Akt phosphorylation (Komazaki et al. 2017). Porphyromonas gingivalis ( $P$. gingivalis) is also more common in the saliva of NASH patients (Yoneda et al. 2012) and antibody titers against fimbriae type 4 relate to fibrosis severity (Nakahara et al. 2018). Further, mice with dental $P$. gingivalis infection and fed with a HFD developed more severe steatosis and fibrosis in comparison to mice without the dental infection. Liver samples of mice with dental $P$. gingivalis infection exhibited lower stearoyl-CoAdesaturase (SCD1) and fatty acid elongase 6 (ELOVL6) levels, which is, however, inconsistent with the higher steatosis rate. These animals also showed increased hepatic levels of unsaturated fatty acids, which might be seen as a protective and compensatory mechanism (Nakahara et al. 2018). Hence, A. actinomycetemcomitans and $P$. gingivalis-related periodontitis may potentiate risk factors for developing insulin resistance, type 2 diabetes and consequently MAFLD.

\section{Chlamydia pneumoniae/trachomatis}

Chlamydia pneumoniae (C. pneumoniae), a respiratory pathogen, and Chlamydia trachomatis (C. trachomatis), one of the most prevalent sexually transmitted organisms, are obligate intracellular Gram-negative bacteria (Di Pietro et al. 2019). In a small study with male patients, it was observed that $C$. pneumoniae IgA seropositivity was significantly more often present in patients suffering from NASH (53.3 vs $5 \%$ ), while this was not the case for IgG (Bolukbas et al. 2005). This correlation might reflect earlier studies that report a link between persistent $C$. pneumoniae infection and the metabolic syndrome (Laurila et al. 1997; Leinonen and Saikku 1999), although conflicting results exist (Falck et al. 2002). Nonetheless, $C$. pneumoniae infection induced dyslipidemic effects in mice and also altered the hepatic expression of genes involved in lipid metabolism, including reduced expression of CPTIA and acyl-CoA dehydrogenase medium chain (ACADM), pointing to compromised mitochondrial fatty acid oxidation. Moreover, expression of liver ILIB mRNA was induced (Marangoni et al. 2015), indicating an inflammatory response.

In addition, $C$. trachomatis infection seems to intervene with hepatic lipid metabolism and inflammation. In Chang Liver cells, $C$. trachomatis induced fatty acid uptake via fatty acid binding protein 1 (L-FABP) expression which promoted chlamydial intracellular growth (Wang et al. 2007). Furthermore, $C$. trachomatis-infected mice showed increased hepatic $I L-6$ and TNFA mRNA expression, which both are typical markers involved in NASH. Yet, this was accompanied with decreased levels of the de novo lipogenic genes acetyl-coenzyme A carboxylase (ACC) and FAS (Marangoni et al. 2015).

Taken together, although a direct link between Chlamydia species infections and MAFLD is lacking, different molecular connections can be made which points to the need for more research in this area, especially when considering the asymptomatic nature of the infection (Di Pietro et al. 2019; Hyman et al. 1995). 


\section{Plasmodium}

Malaria is the most common parasitic mosquito-borne disease (White et al. 2014). The responsible parasites are unicellular protozoan that can cause fever, anemia, coma and death. After mosquito-mediated host entry of sporozoites, the parasite asexually reproduces merozoites in hepatocytes. The first symptoms appear upon the first liver schizont rupture releasing merozoites that are competent to infect erythrocytes. A subset of Plasmodium species is able to infect humans (P. falciparum, P. vivax, P. ovale, $P$. malariae and $P$. knowlesi) (Milner 2018). Most frequent and severe cases are caused by $P$. falciparum and $P$. vivax that together infect over 200 million persons each year. Nearly, all malaria-related deaths result from $P$. falciparum infection (White et al. 2014).

Severe malaria cases often exhibit hepatic dysfunction and jaundice, which histopathologically manifest as hepatocyte necrosis, granulomatous lesions, Kupffer cell hyperplasia, malarial pigmentation, cholestasis and monocyte infiltrations to malarial nodules (Reuling et al. 2018).

Type 2 diabetes mellitus increases the risk for P. falciparum infection which might be due to decreased T cellmediated immunity and increased glucose availability for the parasite (Danquah et al. 2010; Muller et al. 2005). $P$. falciparum infection is generally not associated with MAFLD progression. Yet, severe cases are accompanied by hyperplastic Kupffer cells and portal tract inflammation along with increased NF- $\kappa \mathrm{B}$ p65 and cleaved caspase-3 expression in Kupffer cells and lymphocytes (Viriyavejakul et al. 2014). In accordance, enlarged Kupffer cells have also been seen in the perivenular regions in human NASH liver biopsies (Lefkowitch et al. 2002). Therefore, the interplay between increased risk for $P$. falciparum infection and common hepatic histopathological features of NASH could result in an increased risk for synergetic liver disease progression.

Of note, Plasmodium merozoites require specific fatty acids that cannot be endogenously produced, although essential for development and replication. Mice infected with $P$. chabaudi exhibit hyperproteinemia, hypertriglyceridemia, hypoglycemia, and hypocholesterolemia. Moreover, these mice also show hepatic accumulation of free fatty acids, cholesterol and triglycerides along with promotion of gene- and protein expression of PPAR- $\gamma$ and FAS together with reduced 5' AMP-activated protein kinase (AMPK) phosphorylation. Remarkably, these effects are rescued by metformin treatment, which is an AMPK activator (Kluck et al. 2019). Importantly, metformin also attenuates $P$. falciparum growth in human hepatocytes (Vera et al. 2019), suggesting a possible avenue for drug repurposing.

\section{Toxoplasma gondii}

T. gondii is a protozoan parasite that latently encysts in multiple tissues including skeletal and cardiac muscle, retina, and the central nervous system (Mendez and Koshy 2017). It is estimated that one-third to half of the world population is infected with T. gondii during lifetime (Flegr et al. 2014). In a population-based study, MAFLD was found to positively relate to the presence of $T$. gondii in an age-dependent way (Huang et al. 2018). Yet, no strong evidence exists that $T$. gondii infection is associated with MAFLD and further studies are warranted.

\section{Schistosoma}

Schistosomiasis is caused by flukes of the genus Schistosoma that infect among others liver, intestine, bladder and urethra. Five of these trematodes can infect humans, i.e., S. haematobium, S. intercalatum, S. japonicum, S. mansoni and S. mekongi. Each year, 230-250 million persons are infected worldwide and schistosomiasis is, therefore, the second most common parasitic infection after malaria (Nelwan 2019). In a specific rural Chinese population, it was found that people that previously have undergone schistosomal infection exhibit lower prevalence of diabetes and a better metabolic profile (Chen et al. 2013). Indeed, in vivo and in vitro experiments showed that $S$. japonicum infection leads to reprogramming of liver glycolipid metabolism in the direction of decreased lipogenesis and increased fatty acid catabolism (Xu et al. 2019). Recently, these findings have been confirmed in HFD-fed, $S$. mansoni-infected mice that showed an improvement of their metabolic syndrome features. However, these beneficial effects developed at the expense of more advanced liver injury, suggesting the presence of both favorable as detrimental effects of schistosomal infection (da Silva Filomeno et al. 2020).

\section{Trypanosoma cruzi}

T. cruzi is a protozoan that causes Chagas disease. T. cruzi infection in mice reduces hepatic steatosis and exacerbates TLR4-mediated hepatic inflammation (Onofrio et al. 2015; Lucchetti et al. 2019; Cabalén et al. 2016) which could worsen steatohepatitis. From the opposite perspective, the metabolic syndrome also intensifies Chagas disease in mice during the acute phase of $T$. cruzi infection (Lucchetti et al. 2019), suggesting an interrelationship between the metabolic syndrome, T. cruzi infection and MAFLD.

\section{General remarks and conclusion}

Multiple pathogens may promote or potentiate fatty liver disease and steatohepatitis development, and therefore, synergistically provoke MAFLD progression to end-stage 
liver disease. Studies related to MAFLD are often situated at the interface of pathogen-induced fatty liver disease. This applies to HCV infection and NASH, both characterized by decreased PPARA levels (Dharancy et al. 2005; Francque et al. 2015). HCV (Cheung and Sanyal 2008) and HIV (van Welzen et al. 2019) infections are best known for their liver steatosis- and inflammation-inducing properties. Considering the silent nature of MAFLD, especially asymptomatic infections or colonization by certain pathogens could worsen and accelerate fatty liver disease development throughout life. In contrast, acute highly symptomatic infections that require quick (pharmacological) intervention might readily impact liver physiology and detriment MAFLD as well on the long run. Nonetheless, the causative link between a pathogen and MAFLD deterioration in humans is difficult to establish seen its multifactorial nature. Indeed, Koch's postulates (Byrd and Segre 2016) are most often not fulfilled.

We speculate, however, that although specific molecular and cellular links between infectious diseases and MAFLD can be drawn, pathogens can put additional pressure on an already disturbed immune system, resulting in liver disease deterioration. The liver fulfills an important position in the innate immune system, holding several populations of innate immune cells including Kupffer cells, neutrophils, mast cells and innate-like lymphocytes. Apart from these classical immune cells, also liver sinusoidal endothelial cells and hepatocytes possess important immunogenic properties. Indeed, complement factors, acute phase proteins and extracellular vesicles allow an extrahepatic response through the whole organism (Cai et al. 2019). More specifically, circulating mucosal-associated invariant T (MAIT) cells, important for anti-bacterial and viral defense inter alia in the liver (Jeffery et al. 2016), are reduced in patients with alcoholic or MAFLD-related cirrhosis, while they accumulate in liver fibrotic septa (Hegde et al. 2018). Therefore, more universal mechanisms whether or not additional to specifically disturbed pathways, could lay at the basis of pathogen-related MAFLD progression and vice versa.

The role of adaptive immunity in NASH is an active field of research. Oxidative stress-derived epitopes may be presented to $\mathrm{CD} 4+\mathrm{T}$-helper cells, promoting cytotoxic $\mathrm{CD} 8+\mathrm{T}$ cell responses and $\mathrm{B}$ cell maturation resulting in secretion of anti-oxidative stress-derived epitope IgGs (Sutti and Albano 2020). Oxidative stress is an unspecific response to a variety of causes. Therefore, we hypothesize that infections causing tissue damage and profound inflammatory responses, could potentiate existing NASH by triggering subsequent sterile inflammation (Binder et al. 2016). Further studies are, however, warranted to elucidate the roles of specific pathogens within the multifactorial nature of MAFLD.
Acknowledgements This work was funded by grants of Research Foundation Flanders (1S10518N, 12H2216N, 1S73019N and G042019N), Onderzoeksraad Vrije Universiteit Brussel and the Research Chair Mireille Aerens for the development Alternatives to Animal Testing.

\section{Declarations}

Conflict of interest The authors declare that they have no conflict of interest.

\section{References}

Abu-Shanab A, Quigley EMM (2010) The role of the gut microbiota in nonalcoholic fatty liver disease. Nat Rev Gastroenterol Hepatol 7:691-701. https://doi.org/10.1038/nrgastro.2010.172

Adinolfi LE, Gambardella M, Andreana A et al (2001) Steatosis accelerates the progression of liver damage of chronic hepatitis $\mathrm{C}$ patients and correlates with specific HCV genotype and visceral obesity. Hepatology 33:1358-1364. https://doi.org/10.1053/jhep. 2001.24432

Adinolfi LE, Rinaldi L, Guerrera B et al (2016) NAFLD and NASH in $\mathrm{HCV}$ infection: prevalence and significance in hepatic and extrahepatic manifestations. Int J Mol Sci 17:1-12. https://doi. org/10.3390/ijms 17060803

Alakhali MS, Al-Maweri SA, Al-Shamiri HM et al (2018) The potential association between periodontitis and non-alcoholic fatty liver disease: a systematic review. Clin Oral Investig 22:29652974. https://doi.org/10.1007/s00784-018-2726-1

Alazawi W, Bernabe E, Tai D et al (2017) Periodontitis is associated with significant hepatic fibrosis in patients with non-alcoholic fatty liver disease. PLoS ONE 12:1-13. https://doi.org/10.1371/ journal.pone.0185902

Al-Qahtani AA, Lyroni K, Aznaourova M et al (2017) Middle east respiratory syndrome corona virus spike glycoprotein suppresses macrophage responses via DPP4-mediated induction of IRAK-M and PPAR $\gamma$. Oncotarget 8:9053-9066. https://doi.org/10.18632/ oncotarget. 14754

Alsatie M, Pandya P, Chalasani NP (2008) Insulin resistance, hepatitis C, and liver transplantation. Liver Transplant 14:136-137

Ando T, Ishikawa T, Takagi T et al (2013) Impact of Helicobacter pylori eradication on circulating adiponectin in humans. Helicobacter 18:158-164. https://doi.org/10.1111/hel.12028

Arora K, Program B, Arbor A (2015) Aggregatibacter actinomycetemcomitans, a potent immunoregulator of the periodontal host defense system and alveolar bone homeostasis. Mol Oral Microbiol 31:165-187. https://doi.org/10.1007/128

Assante G, Williams R, Youngson NA (2020) Is the increased risk for MAFLD patients to develop severe COVID-19 linked to perturbation of the gut-liver axis? J Hepatol 77:487-488. https://doi. org/10.1016/j.jhep.2020.05.051

Asselah T, Rubbia-Brandt L, Marcellin P, Negro F (2006) Steatosis in chronic hepatitis C: why does it really matter? Gut 55:123-130. https://doi.org/10.1136/gut.2005.069757

Aye KS, Charngkaew K, Win N et al (2014) Pathologic highlights of dengue hemorrhagic fever in 13 autopsy cases from Myanmar. Hum Pathol 45:1221-1233. https://doi.org/10.1016/j.humpath. 2014.01.022

Bahekar AA, Singh S, Saha S et al (2007) The prevalence and incidence of coronary heart disease is significantly increased in periodontitis: a meta-analysis. Am Heart J 154:830-837. https://doi.org/10.1016/j.ahj.2007.06.037 
Baumeier C, Schlüter L, Saussenthaler S et al (2017) Elevated hepatic DPP4 activity promotes insulin resistance and nonalcoholic fatty liver disease. Mol Metab 6:1254-1263

Begum F, Das S, Mukherjee D et al (2019) Insight into the tropism of dengue virus in humans. Viruses 11:1136. https://doi.org/ 10.3390/v11121136

Beltran PMJ, Cristea IM (2014) The life cycle and pathogenesis of human cytomegalovirus infection: lessons from proteomics. Expert Rev Proteomics 11:697-711. https://doi.org/10.1586/ 14789450.2014.971116.The

Binder CJ, Papac-Milicevic N, Witztum JL (2016) Innate sensing of oxidation-specific epitopes in health and disease. Nat Rev Immunol 16:485-497. https://doi.org/10.1038/nri.2016.63

Boeckmans J, Natale A, Buyl K et al (2018) Human-based systems: mechanistic NASH modelling just around the corner? Pharmacol Res 134:257-267. https://doi.org/10.1016/j.phrs.2018. 06.029

Boeckmans J, Natale A, Rombaut M et al (2020a) Anti-NASH drug development hitches a lift on PPAR agonism. Cells 9:1-20. https://doi.org/10.3390/cells9010037

Boeckmans J, Rodrigues RM, Demuyser T et al (2020b) COVID-19 and drug-induced liver injury: a problem of plenty or a petty point? Arch Toxicol 94:1367-1369. https://doi.org/10.1007/ s00204-020-02734-1

Bolukbas FF, Bolukbas C, Zeyrek F et al (2005) High rate of seropositivity of Chlamydia pneumoniae $\operatorname{IgA}$ in male patients with nonalcoholic steatohepatitis. Dig Dis Sci 50:1141-1145. https:// doi.org/10.1007/s10620-005-2721-7

Brown LM (2000) Helicobacter pylori: epidemiology and routes of transmission. Epidemiol Rev 22:283-297. https://doi.org/10. 1093/oxfordjournals.epirev.a018040

Brown AJ (2008) Viral hepatitis and fatty liver disease: how an unwelcome guest makes pâté of the host. Biochem J 416:15-17. https:// doi.org/10.1042/BJ20081916

Bruno R, Galastri S, Sacchi P et al (2010) Gp120 modulates the biology of human hepatic stellate cells: a link between HIV infection and liver fibrogenesis. Gut 59:513-520. https://doi.org/10.1136/ gut.2008.163287

Bugianesi E, Marchesini G, Gentilcore E et al (2006) Fibrosis in genotype 3 chronic hepatitis $\mathrm{C}$ and nonalcoholic fatty liver disease: role of insulin resistance and hepatic steatosis. Hepatology 44:1648-1655. https://doi.org/10.1002/hep.21429

Buzzetti E, Pinzani M, Tsochatzis EA (2016) The multiple-hit pathogenesis of non-alcoholic fatty liver disease (NAFLD). Metabolism 65:1038-1048. https://doi.org/10.1016/j.metabol.2015.12. 012

Byrd AL, Segre JA (2016) Adapting Koch's postulates: criteria for disease causation must take microbial interactions into account. Science 351:224-226. https://doi.org/10.1126/science.aad6753

Cabalén ME, Cabral MF, Sanmarco LM et al (2016) Chronic trypanosoma cruzi infection potentiates adipose tissue macrophage polarization toward an anti-inflammatory M2 phenotype and contributes to diabetes progression in a diet-induced obesity model. Oncotarget 7:13400-13415. https://doi.org/10.18632/ oncotarget.7630

Cai J, Zhang XJ, Li H (2019) The role of innate immune cells in nonalcoholic steatohepatitis. Hepatology 70:1026-1037. https://doi. org/10.1002/hep.30506

Cannon MJ, Schmid DS, Hyde TB (2010) Review of cytomegalovirus seroprevalence and demographic characteristics associated with infection. Rev Med Virol 20:202-213. https://doi.org/10.1002/ rmv

Carey IM, Critchley JA, Dewilde S et al (2018) Risk of infection in type 1 and type 2 diabetes compared with the general population: a matched cohort study. Diabetes Care 41:513-521. https://doi. org/10.2337/dc17-2131
Castrillon CA, Hincapie JP, Yepes FL et al (2015) Occurrence of red complex microorganisms and Aggregatibacter actinomycetemcomitans in patients with diabetes. J Investig Clin Dent 6:25-31. https://doi.org/10.1111/jicd.12051

Chamroonkul N, Bansal MB (2019) HIV and the liver. Nat Rev Gastroenterol Hepatol 16:1-2. https://doi.org/10.1038/ s41575-018-0085-7

Chan A, Patel K, Naggie S (2017) Genotype 3 infection-the last stand of hepatitis C virus Austin. Drugs 77:131-144. https://doi.org/ 10.1016/j.physbeh.2017.03.040

Chatrath H, Vuppalanchi R, Chalasani N (2012) Dyslipidemia in patients with nonalcoholic fatty liver disease. Semin Liver Dis 32:22-29. https://doi.org/10.1055/s-0032-1306423

Chen Y, Lu J, Huang Y et al (2013) Association of previous schistosome infection with diabetes and metabolic syndrome: a crosssectional study in rural China. J Clin Endocrinol Metab 98:283287. https://doi.org/10.1210/jc.2012-2517

Chen X, Zhang Z, Li H et al (2020) Endogenous ethanol produced by intestinal bacteria induces mitochondrial dysfunction in nonalcoholic fatty liver disease. J Gastroenterol Hepatol 35:20092019. https://doi.org/10.1111/jgh.15027

Cheng Y, Dharancy S, Malapel M, Desreumaux P (2005) Hepatitis C virus infection down-regulates the expression of peroxisome proliferator-activated receptor $\alpha$ and carnitine palmitoyl acyl-CoA transferase 1A. World J Gastroenterol 11:7591-7596. https://doi. org/10.3748/wjg.v11.i48.7591

Cheng JJ, Li JR, Huang MH et al (2016) CD36 is a co-receptor for hepatitis C virus E1 protein attachment. Sci Rep 6:21808. https:// doi.org/10.1038/srep21808

Cheung O, Sanyal AJ (2008) Hepatitis C infection and nonalcoholic fatty liver disease. Clin Liver Dis 12:573-585. https://doi.org/10. 1016/j.cld.2008.03.005

Choi HSJ, Brouwer WP, Zanjir WMR et al (2020) Nonalcoholic steatohepatitis is associated with liver-related outcomes and all-cause mortality in chronic hepatitis B. Hepatology 71:539-548. https:// doi.org/10.1002/hep.30857

Combs JA, Norton EB, Saifudeen ZR et al (2019) Human cytomegalovirus alters host cell mitochondrial function during acute infection. J Virol 94:e01183-19. https://doi.org/10.1128/jvi.01183-19

Cover TL, Blaser MJ (2009) Helicobacter pylori in health and disease. Gastroenterology 136:1863-1873. https://doi.org/10.1053/j.gastro.2009.01.073.Helicobacter

Cui HJ, Tong XL, Li P et al (2004) Serum hepatic enzyme manifestations in patients with severe acute respiratory syndrome: retrospective analysis. World J Gastroenterol 10:1652-1655. https:// doi.org/10.3748/wjg.v10.i11.1652

da Silva Filomeno CE, Costa-Silva M, Corrêa CL et al (2020) The acute schistosomiasis mansoni ameliorates metabolic syndrome in the C57BL/6 mouse model. Exp Parasitol 212:107889. https:// doi.org/10.1016/j.exppara.2020.107889

Danquah I, Bedu-Addo G, Mockenhaupt FP (2010) Type 2 diabetes mellitus and increased risk for malaria infection. Emerg Infect Dis 16:1601-1604. https://doi.org/10.3201/eid1610.100399

Dash NR, Khoder G, Nada AM, Al Bataineh MT (2019) Exploring the impact of Helicobacter pylori on gut microbiome composition. PLoS ONE 14:1-13. https://doi.org/10.1371/journal.pone. 0218274

Davern TJ, Chalasani N, Fontana RJ et al (2011) Acute hepatitis E infection accounts for some cases of suspected drug-induced liver injury. Gastroenterology 141:1665-1672.e9. https://doi.org/10. 1053/j.gastro.2011.07.051

de Silva AP, Kasturiratne A, Liyanage DLMN et al (2008) Is past exposure to hepatitis A protective against progressive fibrosis in non-alcoholic fatty liver disease? Liver Int 28:147-149. https://doi.org/10.1111/j.1478-3231.2007.01605.x 
De Smet V, Verhulst S, van Grunsven LA (2020) Single cell RNA sequencing analysis did not predict hepatocyte infection by SARS-CoV-2. J Hepatol 73:993-995

Dean M, Carrington M, Winkler C et al (1996) Genetic restriction of HIV-1 infection and progression to AIDS by a deletion allele of the CKR5 structural gene. Science 273:1856-1862. https:// doi.org/10.1126/science.273.5283.1856

Del Cornò M, Cappon A, Donninelli G et al (2016) HIV-1 gp120 signaling through TLR4 modulates innate immune activation in human macrophages and the biology of hepatic stellate cells. J Leukoc Biol 100:599-606. https://doi.org/10.1189/jlb. 4a1215-534r

Dharancy S, Malapel M, Perlemuter G et al (2005) Impaired expression of the peroxisome proliferator-activated receptor alpha during hepatitis C virus infection. Gastroenterology 128:334342. https://doi.org/10.1053/j.gastro.2004.11.016

Di Pietro M, Filardo S, Romano S, Sessa R (2019) Chlamydia trachomatis and Chlamydia pneumoniae interaction with the host: latest advances and future prospective. Microorganisms 7:140. https://doi.org/10.3390/microorganisms7050140

Dongiovanni P, Meroni M, Longo M, Fracanzani AL (2020) MAFLD in COVID-19 patients: an insidious enemy. Expert Rev Gastroenterol Hepatol 00:1-6. https://doi.org/10.1080/17474124. 2020.1801417

Eilami O, Nazari A, Dousti M et al (2019) Investigation of HIV/ AIDS prevalence and associated risk factors among female sex workers from 2010 to 2017: a meta-analysis study. HIV/ AIDS Res Palliat Care 11:105-117. https://doi.org/10.2147/ HIV.S196085

Eshraghian A, Hashemi SA, Jahromi AH et al (2009) Helicobacter pylori infection as a risk factor for insulin resistance. Dig Dis Sci 54:1966-1970. https://doi.org/10.1007/s10620-008-0557-7

Falck G, Gnarpe J, Hansson LO et al (2002) Comparison of individuals with and without specific IgA antibodies to Chlamydia pneumoniae: respiratory morbidity and the metabolic syndrome. Chest 122:1587-1593. https://doi.org/10.1378/chest.122.5.1587

Fang L, Karakiulakis G, Roth M (2020) Are patients with hypertension and diabetes mellitus at increased risk for COVID-19 infection? Lancet Respir Med 2600:30116-30118. https://doi.org/10.1016/ s2213-2600(20)30116-8

Feeney ER, Mallon PWG (2010) Impact of mitochondrial toxicity of HIV-1 antiretroviral drugs on lipodystrophy and metabolic dysregulation. Curr Pharm Des 16:3339-3351

Feng Y, Broder CC, Kennedy PA, Berger EA (1996) HIV-1 entry cofactor: functional cDNA cloning of a seven-transmembrane $\mathrm{G}$ protein-coupled receptor. Science 50:572

Finck BN (2018) Targeting metabolism, insulin resistance, and diabetes to treat nonalcoholic steatohepatitis. Diabetes 67:2485-2493. https://doi.org/10.2337/dbi18-0024

Fleck-Derderian S, McClellan W, Wojcicki JM (2017) The association between cytomegalovirus infection, obesity, and metabolic syndrome in U.S. adult females. Obesity 25:626-633. https://doi. org/10.1002/oby.21764

Flegr J, Prandota J, Sovičková M, Israili ZH (2014) Toxoplasmosis-a global threat. Correlation of latent toxoplasmosis with specific disease burden in a set of 88 countries. PLoS One 9.https://doi. org/10.1371/journal.pone.0090203

Fletcher JG, Guimaraes LS, Fidler JL, Kamath PS (2008) The hepatitis $\mathrm{C}$ virus-associated dysmetabolic syndrome. Hepatology 48:1018-1019. https://doi.org/10.1002/hep.22477

Florimond A, Chouteau P, Bruscella P et al (2015) Human hepatic stellate cells are not permissive for hepatitis $\mathrm{C}$ virus entry and replication. Gut 64:957-965. https://doi.org/10.1136/ gutjnl-2013-305634

Francque S, Verrijken A, Caron S et al (2015) PPAR- $\alpha$ gene expression correlates with severity and histological treatment response in patients with non-alcoholic steatohepatitis. J Hepatol 63:164-173. https://doi.org/10.1016/j.jhep.2015.02.019

Frias M, López-López P, Rivero A, Rivero-Juarez A (2018) Role of hepatitis e virus infection in acute-on-chronic liver failure. Biomed Res Int. https://doi.org/10.1155/2018/9098535

Ganesan M, Poluektova LY, Kharbanda KK, Osna NA (2018) Liver as a target of human immunodeficiency virus infection. World J Gastroenterol 24:4728-4737. https://doi.org/10.3748/wjg. v24.i42.4728

Ganz M, Szabo G (2013) Immune and inflammatory pathways in NASH. Hepatol Int 7:771-781. https://doi.org/10.1007/ s12072-013-9468-6

Gao B, Tsukamoto H (2016) Inflammation in alcoholic and nonalcoholic fatty liver disease: friend or foe? Gastroenterology 150:1704-1709. https://doi.org/10.1053/j.gastro.2016.01.025

Gao F, Zheng KI, Wang XB et al (2020) Metabolic associated fatty liver disease increases coronavirus disease 2019 disease severity in nondiabetic patients. J Gastroenterol Hepatol. https://doi. org/10.1111/jgh.15112

Gastaminza P, Dryden KA, Boyd B et al (2010) Ultrastructural and biophysical characterization of hepatitis $\mathrm{C}$ Virus particles produced in cell culture. J Virol 84:10999-11009. https://doi.org/ 10.1128/jvi.00526-10

Giannelli V, Di GV, Iebba V et al (2014) Microbiota and the gutliver axis: bacterial translocation, inflammation and infection in cirrhosis. World J Gastroenterol 20:16795-16810. https:// doi.org/10.3748/wjg.v20.i45.16795

Giovanna F, Bortolotti F, Francesco D (2008) Natural history of chronic hepatitis B: special emphasis on disease progression and prognostic factors. J Hepatol 48:335-352. https://doi.org/ 10.1016/j.jhep.2007.11.011

Gordon DA, Jamil H (2000) Progress towards understanding the role of microsomal triglyceride transfer protein in apolipoproteinB lipoprotein assembly. Biochim Biophys Acta Mol Cell Biol Lipids 1486:72-83. https://doi.org/10.1016/S1388-1981(00) 00049-4

Goustin AS, Derar N, Abou-Samra AB (2013) Ahsg-fetuin blocks the metabolic arm of insulin action through its interaction with the 95-kD $\beta$-subunit of the insulin receptor. Cell Signal 25:981988. https://doi.org/10.1016/j.cellsig.2012.12.011

Guaraldi G, Maurice JB, Marzolini C et al (2020) New drugs for non-alcoholic steatohepatitis and HIV infection: great expectations with a great absent? Hepatology. https://doi.org/10.1002/ hep. 31177

Guentsch A, Puklo M, Preshaw PM et al (2009) Neutrophils in chronic and aggressive periodontitis in interaction with Porphyromonas gingivalis and Aggregatibacter actinomycetemcomitans. J Periodontal Res 44:368-377. https://doi.org/10. 1111/j.1600-0765.2008.01113.x

Haas JT, Vonghia L, Mogilenko DA et al (2019) Transcriptional network analysis implicates altered hepatic immune function in NASH development and resolution. Nat Metab 1:604-614. https://doi.org/10.1038/s42255-019-0076-1

Hamming I, Timens W, Bulthuis MLC et al (2004) Tissue distribution of ACE2 protein, the functional receptor for SARS coronavirus. A first step in understanding SARS pathogenesis. J Pathol 203:631-637. https://doi.org/10.1002/path.1570

Hegde P, Weiss E, Paradis V et al (2018) Mucosal-associated invariant $\mathrm{T}$ cells are a profibrogenic immune cell population in the liver. Nat Commun 9:1-12. https://doi.org/10.1038/ s41467-018-04450-y

Herker E, Harris C, Hernandez C et al (2010) Efficient hepatitis $\mathrm{C}$ virus particle formation requires diacylglycerol acyltransferase-1. Nat Med 16:1295-1298. https://doi.org/10.1038/nm. 2238 
Hoffmann M, Kleine-Weber H, Schroeder S et al (2020) SARS-CoV-2 cell entry depends on ACE2 and TMPRSS2 and is blocked by a clinically proven protease inhibitor. Cell 181:271-280.e8. https:// doi.org/10.1016/j.cell.2020.02.052

Huang J, Zhang H, Liu S et al (2018) Is Toxoplasma gondii infection correlated with nonalcoholic fatty liver disease? - a populationbased study. BMC Infect Dis 18:4-9. https://doi.org/10.1186/ s12879-018-3547-1

Huang C, Wang Y, Li X et al (2020) Clinical features of patients infected with 2019 novel coronavirus in Wuhan, China. Lancet 395:497-506. https://doi.org/10.1016/S0140-6736(20)30183-5

Huerre MR, Trong Lan N, Marianneau P et al (2001) Liver histopathology and biological correlates in five cases of fatal dengue fever in Vietnamese children. Virchows Arch 438:107-115. https://doi. org/10.1007/s004280000329

Huy NT, Van Giang T, Thuy DHD et al (2013) Factors associated with dengue shock syndrome: a systematic review and meta-analysis. PLoS Negl Trop Dis 7:e2412. https://doi.org/10.1371/journal. pntd.0002412

Hyman CL, Roblin PM, Gaydos CA et al (1995) Prevalence of asymptomatic nasopharyngeal carriage of Chlamydia pneumoniae in subjectively healthy adults: assessment by polymerase chain reaction-enzyme immunoassay and culture. Clin Infect Dis 20:1174-1178

Iwasaki T, Hirose A, Azuma T et al (2018) Correlation between ultrasound-diagnosed non-alcoholic fatty liver and periodontal condition in a cross-sectional study in Japan. Sci Rep 8:1-7. https:// doi.org/10.1038/s41598-018-25857-z

Jackel-Cram C, Babiuk LA, Liu Q (2007) Up-regulation of fatty acid synthase promoter by hepatitis $C$ virus core protein: genotype$3 \mathrm{a}$ core has a stronger effect than genotype-1b core. J Hepatol 46:999-1008. https://doi.org/10.1016/j.jhep.2006.10.019

Jan CF, Chen CJ, Chiu YH et al (2006) A population-based study investigating the association between metabolic syndrome and hepatitis B/C infection (Keelung Community-based Integrated Screening Study No. 10). Int J Obes 30:794-799. https://doi.org/ 10.1038/sj.ijo.0803204

Jeffery HC, Van Wilgenburg B, Kurioka A et al (2016) Biliary epithelium and liver B cells exposed to bacteria activate intrahepatic MAIT cells through MR1. J Hepatol 64:1118-1127. https://doi. org/10.1016/j.jhep.2015.12.017

Ji D, Qin E, Xu J et al (2020) Implication of non-alcoholic fatty liver diseases (NAFLD) in patients with COVID-19: a preliminary analysis. J Hepatol. https://doi.org/10.1016/j.jhep.2020.03.044

Joo EJ, Chang Y, Yeom JS et al (2019) Chronic hepatitis B virus infection and risk of dyslipidaemia: a cohort study. J Viral Hepat 26:162-169. https://doi.org/10.1111/jvh.13014

Kahraman A, Sowa JP, Schlattjan M et al (2013) Fetuin-a mRNA expression is elevated in NASH compared with NAFL patients. Clin Sci 125:391-400. https://doi.org/10.1042/CS20120542

Kawaguchi T, Yoshida T, Harada M et al (2004) Hepatitis C virus down-regulates insulin receptor substrates 1 and 2 through upregulation of suppressor of cytokine signaling 3. Am J Pathol 165:1499-1508. https://doi.org/10.1016/S0002-9440(10)63408-6

Kawaguchi T, Ide T, Taniguchi E et al (2007) Clearance of HCV improves insulin resistance, beta-cell function, and hepatic expression of insulin receptor substrate 1 and 2 . Am J Gastroenterol 102:570-576. https://doi.org/10.1111/j.1572-0241.2006. 01038.x

Khuroo MS, Sofi AA (2020) The discovery of hepatitis viruses: agents and disease. J Clin Exp Hepatol. https://doi.org/10.1016/j.jceh. 2020.04.006

Kleiner DE, Brunt EM, Van Natta M et al (2005) Design and validation of a histological scoring system for nonalcoholic fatty liver disease. Hepatology 41:1313-1321. https://doi.org/10.1002/hep. 20701
Kluck GEG, Wendt CHC, Eustaquio do Imperio G, et al (2019) Plasmodium infection induces dyslipidemia and a hepatic lipogenic state in the host through the inhibition of the AMPK-ACC pathway. Sci Rep 9:1-13. https://doi.org/10.1038/s41598-019-51193-x

Knobler H, Schattner A (2005) TNF- $\alpha$, chronic hepatitis C and diabetes: a novel triad. QJM Mon J Assoc Physicians 98:1-6. https:// doi.org/10.1093/qjmed/hci001

Knobler H, Zhornicky T, Sandler A et al (2003) Tumor necrosis factora-induced insulin resistance may mediate the hepatitis $\mathrm{C}$ virusdiabetes association. Am J Gastroenterol 98:2751-2756. https:// doi.org/10.1016/j.amjgastroenterol.2003.06.002

Komazaki R, Katagiri S, Takahashi H et al (2017) Periodontal pathogenic bacteria, Aggregatibacter actinomycetemcomitans affect non-alcoholic fatty liver disease by altering gut microbiota and glucose metabolism. Sci Rep 7:1-14. https://doi.org/10.1038/ s41598-017-14260-9

Kreling A, Cinthia M, Barbisan C et al (2020) Higher frequency of hepatic steatosis at CT among COVID-19-positive patients. Abdom Radiol. https://doi.org/10.1007/s00261-020-02648-7

Kuba K, Imai Y, Rao S et al (2005) A crucial role of angiotensin converting enzyme 2 (ACE2) in SARS coronavirus-induced lung injury. Nat Med 11:875-879. https://doi.org/10.1038/nm1267

Kularatne SAM, Imbulpitiya IVB, Abeysekera RA et al (2014) Extensive haemorrhagic necrosis of liver is an unpredictable fatal complication in dengue infection: a postmortem study. BMC Infect Dis 14:1-10. https://doi.org/10.1186/1471-2334-14-141

Kumar D, Farrell GC, Fung C, George J (2002) Hepatitis C virus genotype 3 is cytopathic to hepatocytes: reversal of hepatic steatosis after sustained therapeutic response. Hepatology 36:1266-1272. https://doi.org/10.1053/jhep.2002.36370

Lang S, Demir M, Martin A et al (2020) Intestinal virome signature associated with severity of nonalcoholic fatty liver disease. Gastroenterology. https://doi.org/10.1053/j.gastro.2020.07.005

Laurila A, Bloigu A, Näyhä S et al (1997) Chlamydia pneumoniae antibodies and serum lipids in Finnish men: cross sectional study. Br Med J 314:1456-1457. https://doi.org/10.1136/bmj.314.7092. 1441

Lee C (2018) Therapeutic modulation of virus-induced oxidative stress via the Nrf2-dependent antioxidative pathway. Oxid Med Cell Longev. https://doi.org/10.1155/2018/6208067

Lee J, Koh K, Kim YE et al (2013) Upregulation of Nrf2 expression by human cytomegalovirus infection protects host cells from oxidative stress. J Gen Virol 94:1658-1668. https://doi.org/10.1099/ vir.0.052142-0

Lefkowitch JH, Haythe JH, Regent N (2002) Kupffer cell aggregation and perivenular distribution in steatohepatitis. Mod Pathol 15:699-704. https://doi.org/10.1097/01.MP.0000019579.30842. 96

Leinonen M, Saikku P (1999) Interaction of Chlamydia pneumoniae infection with other risk factors of atherosclerosis. Am Heart J 138:15-17. https://doi.org/10.1016/s0002-8703(99)70286-3

Lenggenhager D, Pawel S, Honcharova-Biletska H et al (2020) The histologic presentation of hepatitis E reflects patients' immune status and pre-existing liver condition. Mod Pathol. https://doi. org/10.1038/s41379-020-0593-1

Lhomme S, Marion O, Abravanel F et al (2020) Clinical manifestations, pathogenesis and treatment of hepatitis $\mathrm{E}$ virus infections. J Clin Med 9:331. https://doi.org/10.3390/jcm9020331

Liang TJ (2009) Hepatitis B: the virus and disease. Hepatology 49:s13s21. https://doi.org/10.1002/hep.22881.Hepatitis

Lin KY, Chen GJ, Lee YL et al (2017) Hepatitis A virus infection and hepatitis A vaccination in human immunodeficiency viruspositive patients: a review. World J Gastroenterol 23:35893606. https://doi.org/10.3748/wjg.v23.i20.3589

Liu R, Liu Q, He Y et al (2019) Association between Helicobacter pylori infection and nonalcoholic fatty liver: a meta-analysis. 
Medicine (baltimore) 98:e17781. https://doi.org/10.1097/MD. 0000000000017781

Low H, Hoang A, Pushkarsky T et al (2019) HIV disease, metabolic dysfunction and atherosclerosis: a three year prospective study. PLoS ONE 14:1-19. https://doi.org/10.1371/journ al.pone. 0215620

Lucchetti BFC, Boaretto N, Lopes FNC et al (2019) Metabolic syndrome agravates cardiovascular, oxidative and inflammatory dysfunction during the acute phase of Trypanosoma cruzi infection in mice. Sci Rep 9:1-16. https://doi.org/10.1038/ s41598-019-55363-9

Macías J, Pineda JA, Real LM (2017) Non-alcoholic fatty liver disease in HIV infection. AIDS Rev 19:35-46

MacLachlan JH, Cowie BC (2015) Hepatitis B virus epidemiology. Cold Spring Harb Perspect Med 5:1-12. https://doi.org/10. 1101/cshperspect.a021410

Manco M, Marcellini M, Giannone G, Nobili V (2007) Correlation of serum TNF- $\alpha$ levels and histologic liver injury scores in pediatric nonalcoholic fatty liver disease. Am J Clin Pathol 127:954-960. https://doi.org/10.1309/6VJ4DWGYDU0XYJ8Q

Mantovani A, Turino T, Altomari A et al (2019) Association between Helicobacter pylori infection and risk of nonalcoholic fatty liver disease: an updated meta-analysis. Metabolism 96:56-65. https://doi.org/10.1016/j.metabol.2019.04.012

Marangoni A, Fiorino E, Gilardi F et al (2015) Chlamydia pneumoniae acute liver infection affects hepatic cholesterol and triglyceride metabolism in mice. Atherosclerosis 241:471-479. https://doi.org/10.1016/j.atherosclerosis.2015.05.023

Marra F, Svegliati-baroni G (2017) Lipotoxicity and the gut-liver axis in NASH pathogenesis. J Hepatol 68:280-295. https://doi. org/10.1016/j.jhep.2017.11.014

Martina BEE, Koraka P, Osterhaus ADME (2009) Dengue virus pathogenesis: an integrated view. Clin Microbiol Rev 22:564581. https://doi.org/10.1128/CMR.00035-09

Mehta SH, Brancati FL, Strathdee SA et al (2003) Hepatitis C virus infection and incident type 2 diabetes. Hepatology 38:50-56. https://doi.org/10.1053/jhep.2003.50291

Mendez OA, Koshy AA (2017) Toxoplasma gondii: entry, association, and physiological influence on the central nervous system. PLoS Pathog 13:1-12. https://doi.org/10.1371/journal. ppat. 1006351

Miao Z, Xie Z, Miao J et al (2017) Regulated entry of hepatitis C virus into hepatocytes. Viruses 9:1-19. https://doi.org/10.3390/ v9050100

Milner DA (2018) Malaria pathogenesis. Cold Spring Harb Perspect Med 8:1-11. https://doi.org/10.1101/cshperspect.a025569

Minemura M, Tajiri K, Shimizu Y (2014) Liver involvement in systemic infection. World J Hepatol 6:632-642. https://doi.org/10. 4254/wjh.v6.i9.632

Miquilena-Colina ME, Lima-Cabello E, Sánchez-Campos S et al (2011) Hepatic fatty acid translocase CD36 upregulation is associated with insulin resistance, hyperinsulinaemia and increased steatosis in non-alcoholic steatohepatitis and chronic hepatitis C. Gut 60:1394-1402. https://doi.org/10.1136/gut.2010.222844

Mosoian A, Zhang L, Hong F et al (2017) Frontline science: HIV infection of Kupffer cells results in an amplified proinflammatory response to LPS. J Leukoc Biol 101:1083-1090. https://doi.org/ 10.1189/jlb.3hi0516-242r

Moucari R, Asselah T, Cazals-Hatem D et al (2008) Insulin resistance in chronic hepatitis $C$ : association with genotypes 1 and 4, serum HCV RNA level, and liver fibrosis. Gastroenterology 134:416-423. https://doi.org/10.1053/j.gastro.2007.11.010

Muller LMAJ, Gorter KJ, Hak E et al (2005) Increased risk of common infections in patients with type 1 and type 2 diabetes mellitus. Clin Infect Dis 41:281-288. https://doi.org/10.1086/431587
Nagaya T, Tanaka N, Suzuki T et al (2010) Down-regulation of SREBP-1c is associated with the development of burned-out NASH. J Hepatol 53:724-731. https://doi.org/10.1016/j.jhep. 2010.04 .033

Nakahara T, Hyogo H, Ono A et al (2018) Involvement of Porphyromonas gingivalis in the progression of non-alcoholic fatty liver disease. J Gastroenterol 53:269-280. https://doi.org/10.1007/ s00535-017-1368-4

Nelwan ML (2019) Schistosomiasis: life cycle, diagnosis, and control. Curr Ther Res Clin Exp 91:5-9. https://doi.org/10.1016/j.curth eres.2019.06.001

Ng DL, Al HF, Keating MK et al (2020) Clinicopathologic, immunohistochemical, and ultrastructural findings of a fatal case of middle east respiratory syndrome coronavirus infection in the United Arab Emirates, April 2014. Am J Pathol 186:652-658

Ni Y, Lempp FA, Mehrle S et al (2014) Hepatitis B and D viruses exploit sodium taurocholate co-transporting polypeptide for species-specific entry into hepatocytes. Gastroenterology 146:1-14. https://doi.org/10.1053/j.gastro.2013.12.024

Niegawa T, Kimitaka Takitani RT, Ishiro M, Kuroyanagi Y, Keisuke Okasora YM et al (2018) Effects of Helicobacter pylori eradication on serum lipid levels. J Clin Biochem Nutr 62:179-186. https://doi.org/10.3164/jcbn.17

Nseir W, Taha H, Khateeb J et al (2011) Fatty liver is associated with recurrent bacterial infections independent of metabolic syndrome. Dig Dis Sci 56:3328-3334. https://doi.org/10.1007/ s10620-011-1736-5

Onofrio LI, Arocena AR, Paroli AF et al (2015) Trypanosoma cruzi infection is a potent risk factor for non-alcoholic steatohepatitis enhancing local and systemic inflammation associated with strong oxidative stress and metabolic disorders. PLoS Negl Trop Dis 9:1-22. https://doi.org/10.1371/journal.pntd.0003464

Otake K, Omoto S, Yamamoto T et al (2004) HIV-1 Nef protein in the nucleus influences adipogenesis as well as viral transcription through the peroxisome proliferator-activated receptors. AIDS 18:189-198. https://doi.org/10.1097/00002030-20040 1230-00007

Paczosa MK (2016) Klebsiella pneumoniae: going on the offense with a strong defense. Microbiol Mol Biol Rev 80:629-661. https:// doi.org/10.1128/MMBR.00078-15.Address

Paes MV, Lenzi HL, Nogueira ACM et al (2009) Hepatic damage associated with dengue-2 virus replication in liver cells of BALB/c mice. Lab Investig 89:1140-1151. https://doi.org/10.1038/labin vest. 2009.83

Paik JM, Henry L, De AL et al (2019) Mortality related to nonalcoholic fatty United States. Hepatol Commun 3:1459-1471. https://doi. org/10.1002/hep4.1419

Pal D, Dasgupta S, Kundu R et al (2012) Fetuin-A acts as an endogenous ligand of TLR4 to promote lipid-induced insulin resistance. Nat Med 18:1279-1285. https://doi.org/10.1038/nm.2851

Pan L, Huang P, Xie X et al (2020) Metabolic associated fatty liver disease increases the severity of COVID-19: a meta-analysis. Dig Liver Dis 53:153-157

Papagianni M, Tziomalos K (2018) Non-alcoholic fatty liver disease in patients with HIV infection. AIDS Rev 20:171-173. https:// doi.org/10.24875/AIDSRev. 18000008

Patel A, Harrison SA (2012) Hepatitis C virus infection and nonalcoholic steatohepatitis. Gastroenterol Hepatol 8:305-312

Pawlotsky JM (2020) COVID-19 and the liver-related deaths to come. Nat Rev Gastroenterol Hepatol. https://doi.org/10.1038/ s41575-020-0328-2

Pérez-Chaparro PJ, Gonçalves C, Figueiredo LC et al (2014) Newly identified pathogens associated with periodontitis: a systematic review. J Dent Res 93:846-858. https://doi.org/10.1177/00220 34514542468 
Petruzziello A, Marigliano S, Loquercio G et al (2016) Global epidemiology of hepatitis $C$ virus infection: an up-date of the distribution and circulation of hepatitis $\mathrm{C}$ virus genotypes. World J Gastroenterol 22:7824-7840. https://doi.org/10.3748/wjg.v22.i34.7824

Pihlstrom BL, Michalowicz BS, Johnson NW (2005) Periodontal diseases. Lancet 366:1809-1820. https://doi.org/10.1016/S01406736(05)67728-8

Polyzos S, Kountouras J, Zavos C (2009) Nonalcoholic fatty liver disease: the pathogenetic roles of insulin resistance and adipocytokines. Curr Mol Med 9:299-314. https://doi.org/10.2174/ 156652409787847191

Polyzos SA, Perakakis N, Mantzoros CS (2019) Fatty liver in lipodystrophy: a review with a focus on therapeutic perspectives of adiponectin and/or leptin replacement. Metabolism 96:66-82. https://doi.org/10.1016/j.metabol.2019.05.001

Quaresma JAS, Barros VLRS, Pagliari C et al (2006) Revisiting the liver in human yellow fever: virus-induced apoptosis in hepatocytes associated with TGF- $\beta$, TNF- $\alpha$ and NK cells activity. Virology 345:22-30. https://doi.org/10.1016/j.virol.2005.09.058

Quesada-Vázquez S, Aragonès G, Del Bas JM, Escoté X (2020) Diet, gut microbiota and non-alcoholic fatty liver disease: three parts of the same axis. Cells 9:176. https://doi.org/10.3390/cells90101 76

Reuling IJ, de Jong GM, Yap XZ et al (2018) Liver injury in uncomplicated malaria is an overlooked phenomenon: an observational study. EBioMedicine 36:131-139. https://doi.org/10.1016/j. ebiom.2018.09.018

Riddle TM, Kuhel DG, Woollett LA et al (2001) HIV protease inhibitor induces fatty acid and sterol biosynthesis in liver and adipose tissues due to the accumulation of activated sterol regulatory element-binding proteins in the nucleus. J Biol Chem 276:3751437519. https://doi.org/10.1074/jbc.M104557200

Rocafort M, Noguera-Julian M, Rivera J et al (2019) Evolution of the gut microbiome following acute HIV-1 infection. Microbiome 7:1-17. https://doi.org/10.1186/s40168-019-0687-5

Rochira V, Guaraldi G (2017) Growth hormone deficiency and human immunodeficiency virus. Best Pract Res Clin Endocrinol Metab 31:91-111. https://doi.org/10.1016/j.beem.2017.02.006

Ryaboshapkina M, Hammar M (2017) Human hepatic gene expression signature of non-alcoholic fatty liver disease progression, a meta-analysis. Sci Rep 7:1-12. https://doi.org/10.1038/ s41598-017-10930-w

Salvi GE, Carollo-Bittel B, Lang NP (2008) Effects of diabetes mellitus on periodontal and peri-implant conditions: update on associations and risks. J Clin Periodontol 35:398-409. https://doi.org/ 10.1111/j.1600-051X.2008.01282.x

Sasaki R, Devhare PB, Steele R et al (2017) Hepatitis C virus-induced CCL5 secretion from macrophages activates hepatic stellate cells. Hepatology 66:746-757. https://doi.org/10.1002/hep.29170

Seitz R (2010) Human cytomegalovirus (HCMV)-revised. Transfus Med Hemotherapy 37:365-375. https://doi.org/10.1159/00032 2141

Seitz R (2016) Human immunodeficiency virus (HIV). Transfus Med Hemotherapy 43:203-222. https://doi.org/10.1159/000445852

Serfaty L, Andreani T, Giral P et al (2001) Hepatitis C virus induced hypobetalipoproteinemia: a possible mechanism for steatosis in chronic hepatitis C. J Hepatol 34:428-434. https://doi.org/10. 1016/S0168-8278(00)00036-2

Seth H (2019) Fatty liver disease in persons with HIV infection. Top Antivir Med 27:75-82

Shafer RW, Vuitton DA (1999) Highly active antiretroviral therapy (HAART) for the treatment of infection with human immunodeficiency virus type 1. Biomed Pharmacother 53:73-86. https:// doi.org/10.1016/S0753-3322(99)80063-8
Sheikh MY, Choi J, Qadri I et al (2008) Hepatitis C virus infection: molecular pathways to metabolic syndrome. Hepatology 47:2127-2133. https://doi.org/10.1002/hep.22269

Shrivastav S, Kino T, Cunningham T et al (2008) Human immunodeficiency virus (HIV)-1 viral protein R suppresses transcriptional activity of peroxisome proliferator-activated receptor $\gamma$ and inhibits adipocyte differentiation: implications for HIV-associated lipodystrophy. Mol Endocrinol 22:234-247. https://doi.org/10. 1210/me.2007-0124

Simões Quaresma JA, Souza Barros VLR, Rainero Fernandes E et al (2005) Reconsideration of histopathology and ultrastructural aspects of the human liver in yellow fever. Acta Trop 94:116127. https://doi.org/10.1016/j.actatropica.2005.03.003

So-Armah K, Freiberg MS (2018) HIV and cardiovascular disease: update on clinical events, special populations, and novel biomarkers. Curr HIV/AIDS Rep 15:233-244. https://doi.org/10. 1007/s11904-018-0400-5.HIV

Somsouk M, Estes JD et al (2015) Gut epithelial barrier and systemic inflammation during chronic HIV infection. Physiol Behav 29:43-51. https://doi.org/10.1016/j.physbeh.2017.03.040

Stefan N, Häring HU (2013) Circulating fetuin-A and free fatty acids interact to predict insulin resistance in humans. Nat Med 19:394 395. https://doi.org/10.1038/nm.3116

Stefan N, Häring H, Cusi K (2018) Non-alcoholic fatty liver disease: causes, diagnosis, cardiometabolic consequences, and treatment strategies. Lancet Diabetes Endocrinol 8587:1-12. https://doi. org/10.1016/S2213-8587(18)30154-2

Stern JH, Rutkowski JM, Scherer PE (2016) Adiponectin, leptin, and fatty acids in the maintenance of metabolic homeostasis through adipose tissue crosstalk. Cell Metab 23:770-784. https://doi.org/ 10.1016/j.cmet.2016.04.011

Sumida Y, Kanemasa K, Imai S et al (2015) Helicobacter pylori infection might have a potential role in hepatocyte ballooning in nonalcoholic fatty liver disease. J Gastroenterol 50:996-1004. https://doi.org/10.1007/s00535-015-1039-2

Sun DQ, Liu WY, Wu SJ et al (2016) Increased levels of low-density lipoprotein cholesterol within the normal range as a risk factor for nonalcoholic fatty liver disease. Oncotarget 7:5728-5737. https://doi.org/10.18632/oncotarget.6799

Sutti S, Albano E (2020) Adaptive immunity: an emerging player in the progression of NAFLD. Nat Rev Gastroenterol Hepatol 17:8192. https://doi.org/10.1038/s41575-019-0210-2

Suwarto S, Diahtantri RA, Hidayat MJ, Widjaya B (2018) Nonalcoholic fatty liver disease is associated with increased hemoconcentration, thrombocytopenia, and longer hospital stay in dengue-infected patients with plasma leakage. PLoS ONE 13:1-11. https://doi.org/10.1371/journal.pone.0205965

Tandra S, Yeh MM, Brunt EM et al (2011) Presence and significance of microvesicular steatosis in nonalcoholic fatty liver disease. J Hepatol 55:654-659. https://doi.org/10.1016/j.jhep.2010.11.021

Tang DM, Kumar S (2017) The association between Helicobacter pylori infection and nonalcoholic fatty liver disease. Curr Gastroenterol Rep 19:1-5. https://doi.org/10.1007/s11894-017-0545-1

Taylor JM (2018) Hepatitis D virus replication. Cold Spring Harb Perspect Med 5:a021568. https://doi.org/10.1007/978-3-31994355-8_11

Tilton C, Clippinger AJ, Maguire T, Alwine JC (2011) Human cytomegalovirus induces multiple means to combat reactive oxygen species. J Virol 85:12585-12593. https://doi.org/10.1128/jvi. 05572-11

Trepanowski JF, Mey J, Varady KA (2015) Fetuin-A: a novel link between obesity and related complications. Int J Obes 39:734741. https://doi.org/10.1038/ijo.2014.203

Tuyama AC, Hong F, Saiman Y et al (2010) Human immunodeficiency virus (HIV)-1 infects human hepatic stellate cells and promotes collagen I and monocyte chemoattractant protein-1 expression: 
implications for the pathogenesis of HIV/hepatitis C virusinduced liver fibrosis. Hepatology 52:612-622. https://doi.org/ 10.1002/hep.23679.Human

Upala S, Jaruvongvanich V, Riangwiwat T et al (2016) Association between Helicobacter pylori infection and metabolic syndrome: a systematic review and meta-analysis. J Dig Dis 17:433-440. https://doi.org/10.1111/1751-2980.12367

Urban S, Schulze A, Dandri M, Petersen J (2010) The replication cycle of hepatitis B virus. J Hepatol 52:282-284. https://doi.org/10. 1016/j.jhep.2009.10.031

Vallet-Pichard A, Mallet V, Pol S (2012) Nonalcoholic fatty liver disease and HIV infection. Semin Liver Dis 32:158-166. https://doi. org/10.1055/s-0032-1316471

van Welzen BJ, Mudrikova T, El Idrissi A et al (2019) A review of non-alcoholic fatty liver disease in HIV-infected patients: the next big thing? Infect Dis Ther 8:33-50. https://doi.org/10.1007/ s40121-018-0229-7

Vera IM, Grilo Ruivo MT, Lemos Rocha LF et al (2019) Targeting liver stage malaria with metformin. JCI Insight 4:1-10. https://doi.org/ 10.1172/jci.insight. 127441

Viriyavejakul P, Khachonsaksumet V, Punsawad C (2014) Liver changes in severe Plasmodium falciparum malaria: histopathology, apoptosis and nuclear factor kappa B expression. Malar J 13:1-9. https://doi.org/10.1186/1475-2875-13-106

Vlahakis SR, Villasis-Keever A, Gomez TS et al (2003) Human immunodeficiency virus-induced apoptosis of human hepatocytes via CXCR4. J Infect Dis 188:1455-1460. https://doi.org/10.1086/ 379738

Vodkin I, Valasek MA, Bettencourt R et al (2015) Clinical, biochemical and histological differences between HIV-associated NAFLD and primary NAFLD: a case-control study. Aliment Pharmacol Ther 41:368-378. https://doi.org/10.1111/apt.13052

von Loeffelholz C, Horn P, Birkenfeld AL et al (2016) Fetuin A is a predictor of liver fat in preoperative patients with nonalcoholic fatty liver disease. J Investig Surg 29:266-274. https://doi.org/ $10.3109 / 08941939.2016 .1149640$

Waggoner JJ, Rojas A, Pinsky BA (2018) Yellow fever virus: diagnostics for a persistent arboviral threat. J Clin Microbiol 56:1-13. https://doi.org/10.1128/JCM.00827-18

Wang G, Burczynski F, Anderson J, Zhong G (2007) Effect of host fatty acid-binding protein and fatty acid uptake on growth of Chlamydia trachomatis L2. Microbiology 153:1935-1939. https://doi. org/10.1099/mic.0.2006/003491-0

Waris G, Felmlee DJ, Negro F, Siddiqui A (2007) Hepatitis C virus induces proteolytic cleavage of sterol regulatory element binding proteins and stimulates their phosphorylation via oxidative stress. J Virol 81:8122-8130. https://doi.org/10.1128/jvi.00125-07

White AJ (2001) Mitochondrial toxicity and HIV therapy. Sex Transm Infect 77:158-173. https://doi.org/10.1136/sti.77.3.158

White NJ, Pukrittayakamee S, Hien TT et al (2014) Malaria. Lancet 383:723-735. https://doi.org/10.1016/S0140-6736(13)60024-0

Wijarnpreecha K, Thongprayoon C, Panjawatanan P et al (2018) Helicobacter pylori and risk of nonalcoholic fatty liver disease. $\mathrm{J}$ Clin Gastroenterol 52:386-391. https://doi.org/10.1097/MCG. 0000000000000784

Xiong J, Zhang H, Wang Y et al (2017) Hepatitis B virus infection and the risk of nonalcoholic fatty liver disease: a meta-analysis. Oncotarget 8:107295-107302. https://doi.org/10.18632/oncot arget. 22364

Xu ZP, Chang H, Ni YY et al (2019) Schistosoma japonicum infection causes a reprogramming of glycolipid metabolism in the liver. Parasit Vectors 12:1-10. https://doi.org/10.1186/ s13071-019-3621-6
Yan Q, Hruz PW (2005) Direct comparison of the acute in vivo effects of HIV protease inhibitors on peripheral glucose disposal. J Acquir Immune Defic Syndr 40:398-403. https://doi.org/10. 1038/jid.2014.371

Yan H, Zhong G, Xu G et al (2012) Sodium taurocholate cotransporting polypeptide is a functional receptor for human hepatitis B and D virus. Elife 2012:1-28. https://doi.org/10.7554/eLife.00049

Yi Y, Lagniton PNP, Ye S et al (2020) COVID-19: what has been learned and to be learned about the novel coronavirus disease. Int J Biol Sci 16:1753-1766. https://doi.org/10.7150/ijbs.45134

Yoneda M, Naka S, Nakano K et al (2012) Involvement of a periodontal pathogen, Porphyromonas gingivalis on the pathogenesis of nonalcoholic fatty liver disease. BMC Gastroenterol 12:16. https:// doi.org/10.1186/1471-230X-12-16

Younossi Z, Anstee QM, Marietti M et al (2018) Global burden of NAFLD and NASH: trends, predictions, risk factors and prevention. Nat Rev Gastroenterol Hepatol 15:11-20. https://doi.org/10. 1038/nrgastro.2017.109

Younossi ZM, Marchesini G, Pinto-Cortez H, Petta S (2019) Epidemiology of nonalcoholic fatty liver disease and nonalcoholic steatohepatitis: implications for liver transplantation. Transplantation 103:22-27. https://doi.org/10.1097/TP.0000000000002484

Yuan J, Chen C, Cui J et al (2019) Fatty liver disease caused by highalcohol-producing Klebsiella pneumoniae. Cell Metab 30:675688.e7. https://doi.org/10.1016/j.cmet.2019.08.018

Zanto TP, Hennigan K, Östberg M et al (2010) Hepatocellular ballooning in NASH. J Hepatol 53:719-723. https://doi.org/10.1016/j. cortex.2009.08.003.Predictive

Zein NN (2000) Clinical significance of hepatitis C virus genotypes. Clin Microbiol Rev 13:223-235. https://doi.org/10.1128/CMR 13.2.223-235.2000

Zhang X, Shen J, Man K et al (2014) CXCL10 plays a key role as an inflammatory mediator and a non-invasive biomarker of nonalcoholic steatohepatitis. J Hepatol 61:1365-1375. https://doi. org/10.1016/j.jhep.2014.07.006

Zhang X, Wang Y, Qian D et al (2018) HCMV-encoded IE2 promotes NAFLD progression by up-regulation of SREBP1c expression in UL122 genetically modified mice. Int J Clin Exp Pathol 11:4213-4220

Zhang L, Mosoian A, Schwartz ME et al (2019) HIV infection modulates IL- $1 \beta$ response to LPS stimulation through a TLR4-NLRP3 pathway in human liver macrophages. J Leukoc Biol 105:783795. https://doi.org/10.1002/JLB.4A1018-381R

Zhang C, Shi L, Wang F (2020) Liver injury in COVID-19: management and challenges. Lancet Gastroenterol Hepatol 10:20192021. https://doi.org/10.1016/S2468-1253(20)30057-1

Zhao X, Shah D, Sambamoorthi U (2018) Association between chronic hepatitis B infection and metabolic syndrome. J Diabetes Metab Disord 17:223-232. https://doi.org/10.1007/s40200-018-0364-4

Zhu YZ, Qian XJ, Zhao P, Qi ZT (2014) How hepatitis C virus invades hepatocytes: the mystery of viral entry. World J Gastroenterol 20:3457-3467. https://doi.org/10.3748/wjg.v20.i13.3457

Zylberberg H, Rimaniol A, Pol S et al (1999) Soluble tumor necrosis factor receptors in chronic hepatitis C: a correlation with histological fibrosis and activity. J Hepatol 30:185-191. https://doi. org/10.1016/s0168-8278(99)80060-9

Publisher's Note Springer Nature remains neutral with regard to jurisdictional claims in published maps and institutional affiliations. 